\title{
MANCHESTER
}

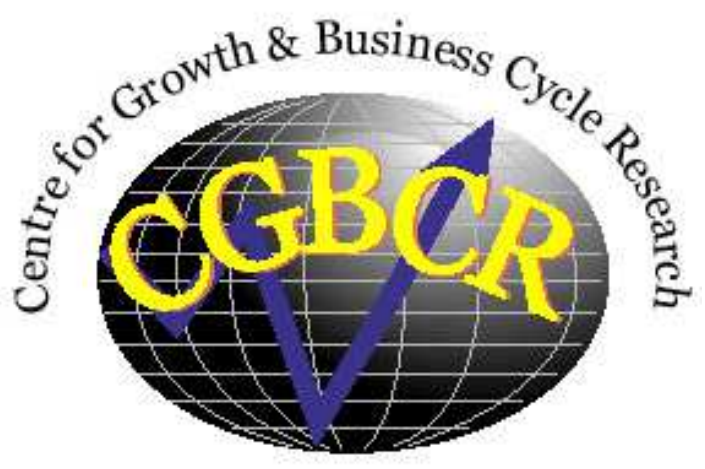

Discussion Paper Series

\section{Capital Controls and Welfare with Cross-Border Bank Capital Flows}

By

\section{Pierre-Richard Agénor and Pengfei Jia}

Centre for Growth and Business Cycle Research, Economic Studies, University of Manchester, Manchester, M13 9PL, UK

September 2015

Number 212

Download paper from:

http://www.socialsciences.manchester.ac.uk/cgbcr/discussionpape rs/index.html 


\title{
Capital Controls and Welfare with Cross-Border Bank Capital Flows
}

\author{
Pierre-Richard Agénor* and Pengfei Jia**
}

\begin{abstract}
This paper studies the performance of time-varying capital controls on crossborder bank borrowing in an open-economy, dynamic stochastic general equilibrium model with credit market frictions and imperfect capital mobility. The model is parameterized for a middle-income country and is shown to replicate the stylized facts associated with a fall in world interest rates (capital inflows, real appreciation, credit boom, asset price pressures, and output expansion). A capital controls rule, which is fundamentally macroprudential in nature, is defined in terms of either changes in bank foreign borrowing or cyclical output. An optimal, welfare-maximizing rule is established numerically. In addition, the optimal simple rule is shown to perform well relative to the Ramsey policy. The analysis is then extended to solve jointly for optimal countercyclical reserve requirements and capital controls rules. The results show that a more aggressive credit-based reserve requirement rule induces less reliance on capital controls. Thus, countercyclical reserve requirements and capital controls are partial substitutes in maximizing welfare.
\end{abstract}

JEL Classification Numbers: E58, F38, F41.

\footnotetext{
${ }^{*}$ University of Manchester, United Kingdom, and Centre for Growth and Business Cycle Research; ** University of Manchester, United Kingdom. We are grateful to Koray Alper, Andrés Fernández, Alessandro Flamini, Christoph Himmels, Luiz Pereira da Silva, and participants at the 2016 Annual Conference of the Royal Economic Society in Brighton, England, the 2016 Annual Conference of the Scottish Economic Society in Perth, Scotland, and the 20th Annual International Conference on Macroeconomic Analysis and International Finance in Rethymno, Greece, for helpful discussions and comments on a preliminary draft. Appendices A and B are available upon request.
} 


\section{Introduction}

Recent experience has shown that surges in capital inflows and outflows can lead to financial instability - in the form of excessive credit growth, asset price pressures and, in some extreme cases, banking crises - even in countries with a floating exchange rate and an independent monetary policy. Temporary capital controls have been increasingly viewed by some economists and policymakers (especially in middle-income countries), as well as international financial institutions like the International Monetary Fund (2012), as a useful instrument for managing financial risks associated with large swings in capital flows, alongside monetary and macroprudential policies.

The case for imposing capital controls is often made on second-best grounds (see Dooley (1996)). Distortions in the domestic financial system, for instance, may cause resources borrowed from abroad to be allocated in socially unproductive ways in the domestic economy. In the absence of a well developed regulatory framework or adequate risk management practices in the financial sector, overborrowing can increase financial vulnerability. If the distortion causing the problem cannot be removed, a second-best option may be to limit foreign borrowing by the financial and nonfinancial sectors.

More recent analytical contributions have focused on the role of capital controls as a prudential instrument, or as a tool to reduce the probability of financial crises. These contributions include Bianchi (2011), Bianchi and Mendoza (2011), Farhi and Werning (2012), Schmitt-Grohé and Uribe (2012), De Paoli and Lipinska (2013), Costinot et al. (2014), Kitano and Takaku (2014), Korinek and Sandri (2014), Brunnermeier and Sannikov (2015), Heathcote and Perri (2016), Davis and Presno (2017), Chang et al. (2015), and Benigno et al. (2016).

One strand of this literature motivates capital controls based on aggregate demand externalities in the presence of nominal frictions on the use of monetary policy. SchmittGrohé and Uribe (2012) discussed the optimal use of capital controls in an economy that is a member of a monetary union when there is downward rigidity in prices. They showed that capital controls can be used as an instrument to overcome the involuntary unemployment caused by wage rigidity. Similarly, Farhi and Werning (2012) argued that a countercyclical capital controls policy can play a role in macroeconomic stabilization in a small open economy with a fixed exchange rate. They also argued that capital controls can mitigate the effects of excess international capital movements caused by 
risk premium shocks. Using a two-country model, De Paoli and Lipińska (2013) showed that restricting international capital flows through capital controls can be beneficial for individual countries, although it would limit international risk sharing. Devereux and Yetman (2014) considered the desirability of capital controls for an economy when its trading partner is in a liquidity trap. They found that capital controls can enhance the scope for monetary policy independence and improve welfare in the face of external shocks.

Another strand of this literature motivates capital controls based on the existence of pecuniary externalities. Benigno et al. (2016) developed models of foreign borrowing subject to collateral constraints and pecuniary externalities in the exchange rate that make the case for taxes on borrowing. They showed that a credible commitment to a price support policy in the event of a financial crisis always welfare-dominates prudential capital controls, because it can achieve the unconstrained allocation. Bengui and Bianchi (2014) considered the implication of an environment in which the ability to enforce capital controls is limited. They showed that while leakages create distortions that make capital controls undesirable, the social planner may find optimal to tighten regulation on the regulated households in order to achieve higher stabilization effects. They also argued that there are important gains from capital controls despite the presence of leakages. Brunnermeier and Sannikov (2015) also studied the implications of pecuniary externalities in a two-country growth model with incomplete markets. Short-term capital flows can be excessive because each firm does not internalize that an increase in production capacity undermines their output price, worsening their terms of trade. In such conditions, capital controls or domestic macro-prudential measures that limit short-term borrowing can improve welfare.

Yet another strand characterizes capital controls as a tool to manage the international terms of trade. De Paoli and Lipińska (2013) described a model in which import and export taxes and subsidies are not available, and capital controls are instead tightened and loosened as competing concerns about output fluctuations gain and lose importance over the business cycle. Costinot et al. (2014) developed a theory of capital controls as dynamic terms-of-trade manipulation. They studied an infinitehorizon endowment economy with two countries in which one country chooses optimal taxes on capital flows while the other country is passive. They showed that it is optimal for the strategic country to tax capital inflows if it grows faster than the rest of 
the world and to tax capital outflows if it grows more slowly. Finally, Heathcote and Perri (2016) considered a two-country, two-good world in which international financial markets are incomplete, in the sense that the only asset traded internationally is a non-contingent bond. This creates prima facie a potential role for policy intervention. The intervention that they consider is an extreme form of capital controls, in which asset trade is ruled out altogether. Thus, they compare welfare when countries only trade a non-contingent, non-defaultable one period bond to welfare under financial autarky. By and large, therefore, the recent literature on capital controls has provided a number of channels through which such controls can improve welfare. ${ }^{1}$

Our analysis differs from existing studies in several important ways. First, as in Escudé (2014), Kitano and Takaku (2014), Chang et al. (2015) and Davis and Presno (2017), we use an open-economy stochastic general equilibrium model to study the benefits of time-varying capital controls. However, unlike these contributions, but in line with Benigno et al. (2016), we do so in a model with financial frictions, a feature that is important to understand some of the negative externalities associated with capital flows from the perspective of financial volatility, such as excessive credit growth or asset price pressures. Second, in contrast to all existing contributions, which tend to focus on controls on households or the nonfinancial sector, we focus on capital controls on bank-related short-term capital flows. Such flows have been an important component of cross-border capital flows in recent years. According to data by the Institute of International Finance for instance, since 2010 net inflows of private capital associated with commercial bank lending have consistently accounted for a larger fraction of total flows than portfolio equity flows to Latin America. In 2014 alone, bank-related capital inflows represented 11.4 percent of nonresident capital inflows, compared to 7.4 percent for portfolio investment flows; in proportion of non-FDI flows, these shares are 18.7 percent and 12.1 percent, respectively. ${ }^{2}$ In countries like Brazil, Indonesia, and Turkey, domestic banks' foreign credit exposures increased substantially in the past decade, de-

\footnotetext{
${ }^{1}$ At the same time, it is worth noting that the empirical evidence on the benefits of capital controls remains ambiguous. For recent contributions and reviews of the evidence on the impact of capital controls, see Binici et al. (2010), Cordero and Montecino (2010), International Monetary Fund (2010, Chapter 4), Magud et al. (2011), Agénor (2012), Klein (2012), Edwards (2012), Agénor and Pereira da Silva (2013), Fernández et al. (2013), Forbes et al. (2015, 2016), Molnar et al. (2013), Eichengreen and Rose (2014), You et al. (2014), Li and Rajan (2015), and Ghosh et al. (2017). It is important to note, however, that few, if any, of these contributions have explicitly analyzed the impact of capital controls on financial stability - measured, in particular, in terms of second-order moments.

${ }^{2}$ See https://www.iif.com/file/10583/download?token=SsHBKQ5j.
} 
spite the partial international deleveraging process that followed the Global financial crisis. $^{3}$ And because in our base experiment capital controls are related to changes in (aggregate) bank foreign borrowing, they are tantamount to a macroprudential instrument. Third, we solve for the optimal, welfare-maximizing capital controls simple rule, using a second-order approximation of the utility function and the model itself. Our analysis shows that temporary capital controls can indeed lead to a significant welfare improvement in response to external financial shocks. In addition, the optimal simple rule performs well relative to the Ramsey policy, both in terms of impulse responses and volatility. Fourth, we study the joint optimal determination of simple, implementable countercyclical rules in terms of both reserve requirements and capital controls. We show that a more aggressive reserve requirement rule (which responds to credit growth) requires less reliance on capital controls. Thus, the two instruments are substitutes at the margin, at least in response to external financial shocks. This is an important result because a common criticism of capital controls (especially when they begin to take a more permanent form) is that private agents find ways to evade them. At the same time, it may be more difficult to do so for reserve requirements.

The remainder of the paper is organized as follows. Section 2 describes the model, which is a simplified version of the model in Agénor et al. (2015). In addition to accounting for capital controls on bank borrowing abroad, the model features imperfect capital mobility and a two-level financial intermediation system, exchange rate smoothing, self insurance, sterilized foreign exchange market intervention, and imperfect substitutability between deposits and central bank borrowing. ${ }^{4}$ The equilibrium and some key features of the steady state are discussed in Section 3, and an illustrative calibration (designed to reproduce the main stylized facts associated with episodes of large capital inflows induced by external financial shocks in the benchmark experiment) is presented in Section 4. The results of a temporary drop in the world safe interest rate, are described in Section 5. As documented in a number of studies, shocks

\footnotetext{
${ }^{3}$ See Hoggarth et al. (2010), Committee on International Economic Policy and Reform (2012), Herrmann and Mihaljek (2013), Reinhardt and Riddiough (2014), Bruno and Shin (2015), Cerutti (2015), Claessens (2017), and McCauley et al. (2017), for a discussion of the importance of crossborder bank flows in international capital movements during the run up to, and the aftermath of, the Global financial crisis. McCauley et al. (2017), in particular, argue that the retreat in international lending in recent years was limited to European banks.

${ }^{4}$ Given the issue at stake, the model is simplified by excluding the cost channel and assuming full sterilization. It also provides a different rationale for imperfect substitutability between deposits and central bank borrowing.
} 
to world interest rates have been a key impulse factor in explaining capital flows (a "sudden flood," in the terminology of Agénor et al. (2014, 2015)) to some of the larger middle-income countries in Asia and Latin America. At the same time, these shocks have imposed significant constraints on policymakers in these countries. Following a drop in the world (risk-free) interest rate for instance, the scope for responding to the risk of macroeconomic and financial instability through monetary policy - above and beyond a "normal" response through a standard Taylor rule - is limited, because higher domestic interest rates would exacerbate capital inflows and magnify currency appreciation. In such conditions, a natural question is to consider which alternatives (capital controls and other macroprudential policies) can be implemented. Welfare-maximizing countercyclical capital controls are discussed in Section 6, whereas the joint determination of countercyclical reserve requirements and capital controls rules are examined in Section 7. The last section provides some concluding remarks and discusses some potentially fruitful directions for future research.

\section{The Model}

Consider a small open economy populated by six categories of agents: a continuum of households with unit mass, a continuum of intermediate goods-producing (IG) firms, indexed by $j \in(0,1)$, a representative final good (FG) producer, a continuum of capital good (CG) producers with unit mass, a continuum of commercial banks, indexed by $i \in(0,1)$, the government, and the central bank. For simplicity, each household is matched to an IG producer, a CG producer, and a bank, and receives profits from all of them. The central bank operates a managed float regime and conducts monetary policy through a standing facility. The country produces a continuum of intermediate goods, which are imperfect substitutes to a continuum of imported intermediate goods. Both categories of goods are combined to produce a homogeneous final good, which is either used for domestic consumption and investment, or exported.

\subsection{Households}

The objective of the representative household is to maximize

$$
U_{t}=\mathbb{E}_{t} \sum_{s=0}^{\infty} \beta^{s}\left\{\frac{C_{t+s}^{1-\varsigma^{-1}}}{1-\varsigma^{-1}}+\eta_{N} \ln \left(1-N_{t+s}\right)+\ln x_{t+s}^{\eta_{x}} H_{t+s}^{\eta_{H}}\right\}
$$


where $C_{t}$ is final good consumption, $N_{t}=\int_{0}^{1} N_{t}^{j} d j$, the share of total time endowment (normalized to unity) spent working, with $N_{t}^{j}$ denoting the number of hours of labor provided to IG producer $j, x_{t}$ a composite index of real monetary assets, $H_{t}$ the stock of housing, $\beta \in(0,1)$ a discount factor, $\varsigma>0$ the intertemporal elasticity of substitution in consumption, $\mathbb{E}_{t}$ the expectation operator conditional on the information available at the beginning of period $t$, and $\eta_{N}, \eta_{x}, \eta_{H}>0$.

The composite monetary asset consists of real cash balances, $m_{t}^{P}$, and real bank deposits, $d_{t}$, both measured in terms of the price of final output, $P_{t}:{ }^{5}$

$$
x_{t}=\left(m_{t}^{P}\right)^{\nu} d_{t}^{1-\nu} . \quad \nu \in(0,1)
$$

The household's flow budget constraint is

$$
\begin{gathered}
m_{t}^{P}+d_{t}+b_{t}^{P}+z_{t} B_{t}^{F, P}+z_{t}^{H} \Delta H_{t} \\
=w_{t} N_{t}-T_{t}-C_{t}+\frac{m_{t-1}^{P}}{1+\pi_{t}}+\left(\frac{1+i_{t-1}^{D}}{1+\pi_{t}}\right) d_{t-1}+\left(\frac{1+i_{t-1}^{B}}{1+\pi_{t}}\right) b_{t-1}^{P} \\
+\left(1+i_{t-1}^{F, P}\right) z_{t} B_{t-1}^{F, P}+J_{t}^{D}+J_{t}^{K}+J_{t}^{B},
\end{gathered}
$$

where $z_{t}=E_{t} / P_{t}$ is the real exchange rate (with $E_{t}$ the nominal exchange rate), $z_{t}^{H}=P_{t}^{H} / P_{t}$ the real price of housing (with $P_{t}^{H}$ the nominal price), $1+\pi_{t}=P_{t} / P_{t-1}, b_{t}^{P}$ $\left(B_{t}^{F, P}\right)$ real (foreign-currency) holdings of one-period, noncontingent domestic (foreign) government bonds, $i_{t}^{D}$ the interest rate on bank deposits, $i_{t}^{B}$ and $i_{t}^{F, P}$ interest rates on domestic and foreign government bonds, respectively, $w_{t}$ the economy-wide real wage, $T_{t}$ real lump-sum taxes, $J_{t}^{D}=\int_{0}^{1}\left(P_{j t}^{D} J_{j t}^{D} / P_{t}\right) d j, J_{t}^{K}$, and $J_{t}^{B}$, end-of-period profits of the matched IG producer, CG producer, and commercial bank. Housing does not depreciate and domestic government bonds are held only at home.

The gross rate of return on foreign bonds is defined as

$$
1+i_{t}^{F, P}=\left(1+i_{t}^{W}\right)\left(1-\theta_{t}^{F, P}\right)
$$

where $i_{t}^{W}$ is the risk-free world interest rate and $\theta_{t}^{F, P}$ an endogenous spread, defined as

$$
\theta_{t}^{F, P}=\frac{\theta_{0}^{F, P}}{2} B_{t}^{F, P}
$$

\footnotetext{
${ }^{5}$ Both deposits and cash are accounted for because in this model with imperfect capital mobility the domestic bond rate is solved (as noted later) from the equilibrium condition of the currency market.
} 
with $\theta_{0}^{F, P}>0$. The household maximizes (1) with respect to $C_{t}, N_{t}, m_{t+1}^{P}, d_{t+1}, b_{t+1}^{P}$, $B_{t+1}^{F, P}$, and $H_{t+1}$, subject to (3), (4), and (5) taking as given period- $t-1$ variables as well as $w_{t}, T_{t}$, and real profits. The first-order conditions are

$$
\begin{gathered}
\mathbb{E}_{t}\left[\left(\frac{C_{t+1}}{C_{t}}\right)^{1 / \varsigma}\right]=\beta \mathbb{E}_{t}\left(\frac{1+i_{t}^{B}}{1+\pi_{t+1}}\right), \\
N_{t}=1-\frac{\eta_{N} C_{t}^{1 / \varsigma}}{w_{t}}, \\
m_{t}^{P}=\frac{\eta_{x} \nu C_{t}^{1 / \varsigma}\left(1+i_{t}^{B}\right)}{i_{t}^{B}}, \\
d_{t}=\frac{\eta_{x}(1-\nu) C_{t}^{1 / \varsigma}\left(1+i_{t}^{B}\right)}{i_{t}^{B}-i_{t}^{D}}, \\
z_{t}^{H} H_{t}^{d}=\left\{1-\mathbb{E}_{t}\left(\frac{1+\pi_{t+1}^{H}}{1+i_{t}^{B}}\right\}^{-1} \eta_{H} C_{t}^{1 / \varsigma},\right. \\
B_{t}^{F, P}=\frac{\left(1+i_{t}^{W}\right) \mathbb{E}_{t}\left(E_{t+1} / E_{t}\right)-\left(1+i_{t}^{B}\right)}{\theta_{0}^{F, P}\left(1+i_{t}^{W}\right) \mathbb{E}_{t}\left(E_{t+1} / E_{t}\right)},
\end{gathered}
$$

where $1+\pi_{t+1}^{H}=P_{t+1}^{H} / P_{t}^{H}$. Equation (11) yields uncovered interest parity when $\theta_{0}^{F, P} \rightarrow 0$.

\subsection{Domestic Final Good}

To produce the final good, $Y_{t}$, a basket of domestically-produced differentiated intermediate goods, $Y_{t}^{D}$, is combined with a basket of imported intermediate goods, $Y_{t}^{F}$ :

$$
Y_{t}=\left[\Lambda_{D}\left(Y_{t}^{D}\right)^{(\eta-1) / \eta}+\left(1-\Lambda_{D}\right)\left(Y_{t}^{F}\right)^{(\eta-1) / \eta}\right]^{\eta /(\eta-1)},
$$

where $\Lambda_{D} \in(0,1)$ and $\eta>0$ is the elasticity of substitution between the two baskets, each of which defined as

$$
Y_{t}^{i}=\left\{\int_{0}^{1}\left[Y_{j t}^{i}\right]^{\left(\theta_{i}-1\right) / \theta_{i}} d j\right\}^{\theta_{i} /\left(\theta_{i}-1\right)} \cdot i=D, F
$$

In this expression, $\theta_{i}>1$ is the elasticity of substitution between intermediate domestic goods among themselves $(i=D)$, and imported goods among themselves $(i=F)$, and $Y_{j t}^{i}$ is the quantity of type- $j$ intermediate good of category $i$, with $j \in$ $(0,1)$.

Cost minimization yields the demand functions for each variety of intermediate goods:

$$
Y_{j t}^{i}=\left(\frac{P_{j t}^{i}}{P_{t}^{i}}\right)^{-\theta_{i}} Y_{t}^{i}, \quad i=D, F
$$


where $P_{j t}^{D}\left(P_{j t}^{F}\right)$ is the price of domestic (imported) intermediate good $j$, and $P_{t}^{D}$ and $P_{t}^{F}$ are price indices, which are given from the zero-profit condition as

$$
P_{t}^{i}=\left\{\int_{0}^{1}\left(P_{j t}^{i}\right)^{1-\theta_{i}} d j\right\}^{1 /\left(1-\theta_{i}\right)}, \quad i=D, F
$$

so that $P_{t}^{i} Y_{t}^{i}=\int_{0}^{1} P_{j t}^{i} Y_{j t}^{i} d j$. Demand for baskets of domestic and foreign goods is

$$
Y_{t}^{D}=\Lambda_{D}^{\eta}\left(\frac{P_{t}^{D}}{P_{t}}\right)^{-\eta} Y_{t}, \quad Y_{t}^{F}=\left(1-\Lambda_{D}\right)^{\eta}\left(\frac{P_{t}^{F}}{P_{t}}\right)^{-\eta} Y_{t}
$$

where $P_{t}$ is the price of final output, given by

$$
P_{t}=\left[\Lambda_{D}^{\eta}\left(P_{t}^{D}\right)^{1-\eta}+\left(1-\Lambda_{D}\right)^{\eta}\left(P_{t}^{F}\right)^{1-\eta}\right]^{1 /(1-\eta)} .
$$

We assume local currency pricing with imperfect pass-through and no transportation costs. The domestic-currency price of imported good $j$ is thus given by

$$
P_{j t}^{F}=E_{t}^{\mu^{F}} E_{t-1}^{1-\mu^{F}}
$$

where the foreign-currency price is normalized to unity and $\mu^{F} \in(0,1)$ measures the degree of exchange rate pass-through. Thus, the law of one price holds only in the steady state.

Exports, $Y_{t}^{X}$, depend on the domestic-currency price of exports (which equals the exchange rate if the foreign-currency price is normalized to unity), relative to the price of goods sold domestically, $P_{t}^{S}$ :

$$
Y_{t}^{X}=\left(\frac{E_{t}}{P_{t}^{S}}\right)^{\varkappa} . \quad \varkappa>0
$$

Total output is thus also given by

$$
Y_{t}=Y_{t}^{S}+Y_{t}^{X}
$$

where $Y_{t}^{S}$ denotes the volume of final goods sold on the domestic market.

\subsection{Domestic Intermediate Goods}

Output of intermediate good $j, Y_{j t}^{D}$, is sold on a monopolistically competitive market and is produced by combining labor, $N_{j t}$, and beginning-of-period capital, $K_{j t}$ :

$$
Y_{j t}^{D}=N_{j t}^{1-\alpha} K_{j t}^{\alpha}, \quad \alpha \in(0,1)
$$


Capital is rented from a randomly matched CG producer (at the rate $r_{t}^{K}$ ) and paid for after the sale of output. Cost minimization yields the capital-labor ratio and the unit real marginal cost, $m c_{t}$, as

$$
\begin{aligned}
\frac{K_{j t}}{N_{j t}} & =\left(\frac{\alpha}{1-\alpha}\right)\left(\frac{w_{t}}{r_{t}^{K}}\right), \quad \forall i \\
m c_{t} & =\left(\frac{r_{t}^{K}}{\alpha}\right)^{\alpha}\left(\frac{w_{t}}{1-\alpha}\right)^{1-\alpha} .
\end{aligned}
$$

Each firm $j$ chooses a sequence of prices so as to maximize the discounted present value of its profits:

$$
\left\{P_{j t+s}^{D}\right\}_{s=0}^{\infty}=\arg \max \mathbb{E}_{t} \sum_{s=0}^{\infty} \beta^{s} \lambda_{t+s} J_{j t+s}^{D},
$$

where $\beta^{s} \lambda_{t+s}$ measures the marginal utility value to the representative household of an additional unit of real profits, $J_{j t+s}^{D}$, received in the form of dividends at $t+s$. In Rotemberg fashion, prices are costly to adjust; profits are thus defined as

$$
J_{j t}^{D}=\left(\frac{P_{j t}^{D}}{P_{t}^{D}}\right) Y_{j t}^{D}-m c_{t} Y_{j t}^{D}-\frac{\phi_{D}}{2}\left(\frac{P_{j t}^{D}}{P_{j t-1}^{D}}-1\right)^{2} Y_{t}^{D},
$$

where $\phi_{D} \geq 0$.

Using (14), the first-order condition for this problem takes the standard form

$$
\begin{gathered}
\left(1-\theta_{D}\right)\left(\frac{P_{j t}^{D}}{P_{t}^{D}}\right)^{-\theta_{D}} \frac{1}{P_{t}^{D}}+\theta_{D}\left(\frac{P_{j t}^{D}}{P_{t}^{D}}\right)^{-\theta_{D}-1} \frac{m c_{t}}{P_{t}^{D}} \\
-\phi_{D}\left\{\left(\frac{P_{j t}^{D}}{P_{j t-1}^{D}}-1\right) \frac{1}{P_{j t-1}^{D}}\right\}+\beta \phi_{D} \mathbb{E}_{t}\left\{\frac{\lambda_{t+1}}{\lambda_{t}}\left(\frac{P_{j t+1}^{D}}{P_{j t}^{D}}-1\right) \frac{P_{j t+1}^{D}}{\left(P_{j t}^{D}\right)^{2}} \frac{Y_{t+1}^{D}}{Y_{t}^{D}}\right\}=0 .
\end{gathered}
$$

\subsection{Capital Good}

The capital stock of the representative CG producer, $K_{t}$, is obtained by combining gross investment, $I_{t}$, with the existing capital stock, adjusted for depreciation and adjustment costs:

$$
K_{t+1}=I_{t}+\left\{1-\delta-\frac{\Theta_{K}}{2}\left(\frac{K_{t+1}-K_{t}}{K_{t}}\right)^{2}\right\} K_{t},
$$

where $\delta \in(0,1)$ is the depreciation rate and $\Theta_{K}>0$.

Investment goods must be paid for in advance. The repressentative $\mathrm{CG}$ producer must therefore borrow from banks $l_{t}^{I}=I_{t}$. The matched household makes its exogenous 
housing stock, $\bar{H}$, available without any direct charge to the CG producer, who uses it as collateral against which it borrows from banks. Repayment is uncertain and occurs with probability $q_{t} \in(0,1)$, which depends on average behavior and is thus taken as given by each CG producer. Expected repayment is thus $q_{t}\left(1+i_{t}^{L}\right) I_{t}+\left(1-q_{t}\right) \kappa z_{t}^{H} \bar{H}$, where $\kappa=\int_{0}^{1} \kappa^{i} d i$ and $\kappa^{i} \in(0,1)$ is the fraction of the housing stock pledged as collateral to each bank $i$.

Subject to (27) and $l_{t}^{I}=I_{t}$ the CG producer chooses the level of capital $K_{t+1}$ so as to maximize the value of the discounted stream of dividend payments to the matched household. As shown by Agénor et al. (2014, 2015), the solution to this problem yields

$$
\begin{aligned}
& \mathbb{E}_{t} r_{t+1}^{K}=q_{t}\left(1+i_{t}^{L}\right) \mathbb{E}_{t}\left\{\left[1+\Theta_{K}\left(\frac{K_{t+1}}{K_{t}}-1\right)\right]\left(\frac{1+i_{t}^{B}}{1+\pi_{t+1}}\right)\right\} \\
& -\mathbb{E}_{t}\left\{q_{t+1}\left(1+i_{t+1}^{L}\right)\left\{1-\delta+\frac{\Theta_{K}}{2}\left[\left(\frac{K_{t+2}}{K_{t+1}}\right)^{2}-1\right]\right\}\right\} .
\end{aligned}
$$

The amount borrowed by the representative CG producer is a Dixit-Stiglitz basket of differentiated loans, each supplied by a bank $i$, with an elasticity of substitution $\zeta^{L}>1$ :

$$
l_{t}^{I}=\left[\int_{0}^{1}\left(l_{t}^{I, i}\right)^{\left(\zeta^{L}-1\right) / \zeta} d i\right]^{\zeta^{L} /\left(\zeta^{L}-1\right)} .
$$

The demand for type- $i$ loan, $l_{t}^{I, i}$, is thus given by the downward-sloping curve

$$
l_{t}^{I, i}=\left(\frac{1+i_{t}^{L, i}}{1+i_{t}^{L}}\right)^{-\zeta^{L}} l_{t}^{I},
$$

where $i_{t}^{L, i}$ is the rate on the loan extended by bank $i$ and $1+i_{t}^{L}=\left[\int_{0}^{1}\left(1+i_{t}^{L, i}\right)^{1-\zeta^{L}} d i\right]^{1 /\left(1-\zeta^{L}\right)}$ the aggregate loan rate.

\subsection{Commercial Banks}

Bank $i$ 's balance sheet is

$$
l_{t}^{I, i}+R R_{t}^{i}=d_{t}^{i}+z_{t} L_{t}^{F, B, i}+l_{t}^{C, B, i}
$$

where $L_{t}^{F, B, i}$ is foreign borrowing (in foreign-currency terms), $l_{t}^{C, B, i}$ borrowing from the central bank, and $R R_{t}^{i}$ required reserves, which are held permanently at the central bank and do not pay interest; they are set as a fraction $\mu_{t}^{R} \in(0,1)$ of deposits:

$$
R R_{t}^{i}=\mu_{t}^{R} d_{t}^{i}
$$


Thus, banks lend to CG producers and hold reserves as assets, whereas their liabilities consist of deposits and borrowing domestically and abroad.

The aggregate supply of deposits by households is a basket of differentiated deposits, each supplied to a bank $i$, with a constant elasticity of substitution $\zeta^{D}>1$ between different types of deposits:

$$
d_{t}=\left[\int_{0}^{1}\left(d_{t}^{i}\right)^{\left(1+\zeta^{D}\right) / \zeta^{D}} d i\right]^{\zeta^{D} /\left(1+\zeta^{D}\right)}
$$

The supply of type- $i$ deposit, $d_{t}^{i}$, is thus given by the upward-sloping curve

$$
d_{t}^{i}=\left(\frac{1+i_{t}^{D, i}}{1+i_{t}^{D}}\right)^{\zeta^{D}} d_{t}
$$

where $1+i_{t}^{D, i}$ is the deposit rate set by bank $i$ and $1+i_{t}^{D}=\left[\int_{0}^{1}\left(1+i_{t}^{D, i}\right)^{1+\zeta^{D}} d i\right]^{1 /\left(1+\zeta^{D}\right)}$ the aggregate deposit rate.

Bank $i$ 's cost of borrowing on world capital markets, $i_{t}^{F, B, i}$, is defined as

$$
1+i_{t}^{F, B, i}=\left(1+\tau_{t}^{B}\right)\left(1+i_{t}^{W}\right)\left(1+\theta_{t}^{F, B, i}\right)
$$

where $\tau_{t}^{B} \in(0,1)$ is a (Pigovian) tax imposed by the central bank and $\theta_{t}^{F, B}$ is a risk premium that increases with the amount borrowed:

$$
\theta_{t}^{F, B, i}=\frac{\theta_{0}^{F, B}}{2} L_{t}^{F, B, i} \cdot \quad \theta_{0}^{F, B}>0
$$

Bank $i$ 's expected profits at end of period $t$ (or beginning of $t+1$ ) are defined as

$$
\begin{gathered}
\mathbb{E}_{t}\left[\left(1+\pi_{t+1}\right) J_{t+1}^{B, i}\right]=q_{t}\left(1+i_{t}^{L, i}\right) l_{t}^{I, i}+\left(1-q_{t}^{i}\right) \kappa^{i} z_{t}^{H} \bar{H}-\left(1+i_{t}^{D, i}\right) d_{t}^{i} \\
-\left(1+i_{t}^{C}\right) l_{t}^{C, B, i}-\left(1+i_{t}^{F, B, i}\right) \mathbb{E}_{t}\left(\frac{E_{t+1}}{E_{t}}\right) z_{t} L_{t}^{F, B, i}
\end{gathered}
$$

where $i_{t}^{C}$ is the marginal cost of borrowing from the central bank.

Each bank sets the gross deposit and lending rates and determines foreign borrowing so as to maximize expected profits (35) subject to (30)-(34). This yields, in a symmetric equilibrium,

$$
\begin{gathered}
1+i_{t}^{D, i}=\frac{\zeta^{D}}{1+\zeta^{D}}\left(1-\mu_{t}^{R}\right)\left(1+i_{t}^{C}\right), \\
1+i_{t}^{L}=\left(\frac{\zeta^{L}}{\zeta^{L}-1}\right)\left(\frac{1+i_{t}^{C}}{q_{t}}\right), \\
L_{t}^{F, B}=\frac{\left(1+i_{t}^{C}\right)-\left(1+\tau_{t}^{B}\right)\left(1+i_{t}^{W}\right) \mathbb{E}_{t}\left(E_{t+1} / E_{t}\right)}{\theta_{0}^{F, B}\left(1+\tau_{t}^{B}\right)\left(1+i_{t}^{W}\right) \mathbb{E}_{t}\left(E_{t+1} / E_{t}\right)} .
\end{gathered}
$$


The repayment probability depends positively on the expected value of collateral relative to the volume of loans, and the cyclical position of the economy:

$$
q_{t}=\left(\frac{\kappa \mathbb{E}_{t} z_{t+1}^{H} \bar{H}}{l_{t}^{I}}\right)^{\varphi_{1}}\left(\frac{Y_{t}}{\tilde{Y}}\right)^{\varphi_{2}}, \quad \varphi_{1}, \varphi_{2}>0
$$

where $\tilde{Y}$ is the steady-state level of final output. Agénor and Pereira da Silva (2017) derive an equation similar to (39) as part of the representative bank's optimization problem by assuming that monitoring costs are endogenous and that monitoring effort is related one-to-one with the probability of repayment - a common assumption in the theoretical literature on banking (see for instance Allen et al. (2011) and Dell'Ariccia et al. (2014)). The collateral-loan ratio reflects a moral hazard effect, whereas the cyclical position of the economy reflects the fact that in boom times monitoring is less costly.

\subsection{Central Bank}

The balance sheet of the central bank is given by

$$
z_{t} R_{t}^{F}+b_{t}^{C}+l_{t}^{C, B}-n w_{t}=m_{t}+R R_{t}
$$

where $z_{t} R_{t}^{F}$ denotes international reserves, $b_{t}^{C}$ holdings of government bonds, $m_{t}$ the real supply of cash, and $n w_{t}$ the central bank's real net worth.

The central bank's reserve accumulation rule is defined as

$$
R_{t}^{F}=\left(\frac{\mathbb{E}_{t} E_{t+1}}{E_{t}}\right)^{-\varphi_{1}^{R}}\left(R_{t-1}^{F}\right)^{\varphi_{2}^{R}}\left\{\left(Y_{t}^{F}\right)^{\varphi^{R}}\left(L_{t}^{F, B}-B_{t}^{F, P}\right)^{1-\varphi^{R}}\right\}^{1-\varphi_{2}^{R}}
$$

where $L_{t}^{F, B}-B_{t}^{F, P}$ denotes net private foreign-currency liabilities, $Y_{t}^{F}$ imports, $\varphi_{1}^{R} \geq 0$ the degree of exchange rate smoothing, $\varphi_{2}^{R} \in(0,1)$ the degree of persistence, and $\varphi^{R} \in$ $(0,1)$ the relative importance of the "trade" motive versus the "financial" motive in targeting reserves. The presence of the exchange rate in rule (41) is consistent with the evidence that middle-income countries tend to intervene frequently and systematically in the foreign exchange market to resist currency appreciation pressures. ${ }^{6}$

Foreign exchange intervention is fully sterilized through open-market operations:

$$
z_{t} \Delta R_{t}^{F}+b_{t}^{C}-\frac{b_{t-1}^{C}}{1+\pi_{t}}=0
$$

\footnotetext{
${ }^{6}$ See Daude et al. (2016) and Ghosh et al. (2017) for empirical evidence. We also experimented with the expected real exchange rate in the reserve accumulation equation. However, this did not make a significant difference to the results.
} 
All income received by the central bank is transferred to the government; thus, changes in the nominal value of the central bank's net worth are given by capital gains associated with exchange rate depreciation $\left(\Delta N W_{t}=R_{t}^{F} \Delta E_{t}\right)$. Combining this result with (40) and (42)yields

$$
m_{t}=\frac{m_{t-1}}{1+\pi_{t}}+\left(l_{t}^{C, B}-\frac{l_{t-1}^{C, B}}{1+\pi_{t}}\right)-\left(R R_{t}-\frac{R R_{t-1}}{1+\pi_{t}}\right) .
$$

The central bank supplies liquidity elastically to commercial banks, at a price that reflects both a base policy rate, $i_{t}^{R}$, and a penalty charge. The base policy rate is set through a Taylor rule:

$$
\frac{1+i_{t}^{R}}{1+\tilde{\imath}^{R}}=\left(\frac{1+i_{t-1}^{R}}{1+\tilde{\imath}^{R}}\right)^{\chi}\left\{\left(\frac{1+\pi_{t}^{S}}{1+\pi^{S, T}}\right)^{\varepsilon_{1}}\left(\frac{Y_{t}}{\tilde{Y}}\right)^{\varepsilon_{2}}\right\}^{1-\chi},
$$

where $\tilde{\imath}^{R}$ is the steady-state value of the policy rate, $\pi^{S, T} \geq 0$ the central bank's headline inflation target in terms of the price of goods sold domestically, $\chi \in(0,1)$ and $\varepsilon_{1}, \varepsilon_{2}>0$.

The actual cost of borrowing from the central bank is given by

$$
1+i_{t}^{C}=\left(1+i_{t}^{R}\right)\left(1+\theta_{t}^{C, B}\right),
$$

where $\theta_{t}^{C, B}$ represents a penalty rate, which is positively related to the ratio of central bank borrowing to required reserves:

$$
\theta_{t}^{C, B}=\theta_{0}^{C, B}\left(\frac{l_{t}^{C, B}}{R R_{t}}\right),
$$

with $\theta_{0}^{C, B}>0$. Thus, the penalty rate increases with the amount borrowed and falls with the amount of reserves held at the central bank, which act as (implicit) collateral, as for instance in Barnea et al. (2015). However, here collateral determines not the amount that can be borrowed from the central bank but rather the cost at which such borrowing occurs. This specification captures in a simple manner imperfect substitutability between (domestic) funding sources for commercial banks - a necessary condition for reserve requirements to be effective as a countercyclical instrument. If the demand for deposits is sufficiently elastic, an increase in the required reserve ratio lowers the deposit rate as well as deposits and total required reserves, and therefore raises the premium at the initial level of central bank borrowing. The presence of imperfect substitution makes it therefore more expensive for financial intermediaries to replace deposits with central bank borrowing, and this increase in cost tends to feed into the market loan rate. 


\subsection{Government}

The government budget constraint is given by

$$
\begin{gathered}
b_{t}-\frac{b_{t-1}}{1+\pi_{t}}=G_{t}-T_{t}+\frac{i_{t-1}^{B} b_{t-1}^{P}}{1+\pi_{t}} \\
+\tau_{t-1}^{B} i_{t-1}^{W} z_{t} \frac{L_{t-1}^{F, B}}{1+\pi_{t}}-\left(\frac{i_{t-1}^{C} l_{t-1}^{C, B}}{1+\pi_{t}}+z_{t} i_{t-1}^{W} R_{t-1}^{F}\right),
\end{gathered}
$$

where $b_{t}=b_{t}^{C}+b_{t}^{P}$ is the real stock of riskless one-period bonds, and $G_{t}$ real expenditure, which represents a fraction $\psi \in(0,1)$ of domestic sales of the final good:

$$
G_{t}=\psi Y_{t}^{S}
$$

In what follows the government is assumed to keep its real stock of debt constant $\left(b_{t}=b\right.$, for all $\left.t\right)$ and to balance its budget by adjusting lump-sum taxes.

\section{Equilibrium and Steady State}

In a symmetric equilibrium, $K_{j t}=K_{t}, N_{j t}=N_{t}, Y_{j t}=Y_{t}, P_{j t}^{i}=P_{t}^{i}$, for all $j \in(0,1)$ and $i=D, F$. Equilibrium in the goods market requires that sales on the domestic market be equal to domestic absorption inclusive of price adjustment costs, which are paid in real units:

$$
Y_{t}^{S}=C_{t}+G_{t}+I_{t}+\frac{\phi_{D}}{2}\left(\frac{P_{t}^{D}}{P_{t-1}^{D}}-1\right)^{2}\left(\frac{P_{t}^{D}}{P_{t}^{S}}\right) Y_{t}^{D},
$$

with the price of sales on the domestic market determined through the identity

$$
P_{t} Y_{t}=P_{t}^{S} Y_{t}^{S}+P_{t}^{X} Y_{t}^{X}
$$

Bank loans are made in the form of cash. The equilibrium condition of the currency market is thus

$$
m_{t}=m_{t}^{P}+l_{t}^{I}
$$

where $m_{t}$ is defined in (43).

The equilibrium condition of the housing market is

$$
\bar{H}=H_{t},
$$

which can be solved, using (10), to determine the dynamics of house prices. 
The balance of payments is given by

$$
Y_{t}^{X}-Y_{t}^{F}+i_{t-1}^{W} F_{t-1}+\theta_{t-1}^{F, P} B_{t-1}^{F, P}-\theta_{t-1}^{F, B} L_{t-1}^{F, B}-\Delta F_{t}=0
$$

where $F_{t}=R_{t}^{F}+B_{t}^{F, P}-L_{t}^{F, B}$ is the economy's net foreign asset position.

Finally, the risk-free world interest rate follows a first-order autoregressive process:

$$
\frac{1+i_{t}^{W}}{1+\tilde{\imath}^{W}}=\left(\frac{1+i_{t-1}^{W}}{1+\tilde{\imath}^{W}}\right)^{\rho_{W}} \exp \left(\xi_{t}^{W}\right)
$$

where $\rho_{W} \in(0,1)$ and the serially uncorrelated innovation $\xi_{t}^{W}$ is normally distributed with mean zero and standard deviation $\sigma_{\xi^{W}}$.

The steady-state solution of the model is derived in Appendix A. Its key features are similar to those described in Agénor et al. (2015), so we refer to that paper for a more detailed discussion.

\section{Parameterization}

The model is parameterized so that it reproduces in the benchmark experiment the main stylized facts associated with episodes of large capital inflows induces by financial "push" factors (real appreciation, current account deficit, lower interest rates, a credit boom, output expansion, and asset price pressures), as documented in Agénor and Montiel (2015) and Caballero (2016) for instance. Parameter values, which dwell in part on Agénor et al. (2015), are summarized in Table 1.

The discount factor $\beta$ is set at 0.985 , which gives an annual real interest rate of 6.2 percent. The intertemporal elasticity of substitution, $\varsigma$, is 0.5 , in line with estimates for middle-income countries (see Agénor and Montiel (2015)). The preference parameter for leisure, $\eta_{N}$, is set at 10 , to ensure that in the steady state households devote one third of their time endowment to market activity, as in Gertler et al. (2007) for instance. The preference parameters for composite monetary assets, $\eta_{x}$, is set at a low value, 0.02 , to capture the common assumption in the literature that their weight in household preferences is negligible (see for instance Coenen et al. (2009)). The same value is used for the housing preference parameter, $\eta_{H}$. The share parameter in the index of money holdings, $\nu$, which corresponds to the relative share of cash in narrow money, is set at 0.35 . This value is consistent with available data for middle-income countries. The sensitivity of the spread to household foreign bond holdings is set at 0.5 . 
The distribution parameter between domestic and imported intermediated goods in the production of the final good, $\Lambda_{D}$, is set at 0.7 , to capture the case of a middleincome economy where imports are about a third of GDP, as in Medina and Roldós (2014) for instance. The elasticity of substitution between baskets of domestic and imported composite intermediate goods, $\eta$, is set at 1.5 , a fairly standard value in the literature. The elasticities of substitution between intermediate domestic goods among themselves, $\theta_{D}$, and imported goods among themselves, $\theta_{F}$, are set equal at 10 . The pass-through coefficient is set at $\mu^{F}=0.3$, which is in line with the evidence on the strength of the pass-through effect in Latin America (see Inter-American Development Bank (2015, Appendix C)). The price elasticity of exports, $\varkappa$, is set equal to 0.9, which is close to the value of unity used by Gertler et al. (2007) for Korea.

The share of capital in domestic output of intermediate goods, $\alpha$, is set at 0.35 . With $\theta_{D}=10$, the steady-state value of the markup rate, $\theta_{D} /\left(\theta_{D}-1\right)$, is equal to 11.1 percent. The adjustment cost parameter for prices of domestic intermediate goods, $\phi_{D}$, is set at 74.5. This value implies a Calvo-type probability of not adjusting prices of approximately 0.71 percent per period or equivalently an average period of price fixity of about 3.5 quarters. These figures are consistent with the estimates of Carvalho et al. (2014, Table 2) for Brazil. The rate of depreciation of private capital, $\delta$, is set equal to 0.02 . The adjustment cost incurred by the $\mathrm{CG}$ producer for transforming the final good into investment, $\Theta_{K}$, is set at 14, to generate an investment path in response to shocks that is 2 to 3 times more volatile than domestic output, as documented in studies of macroeconomic fluctuations in developing countries (see Neumeyer and Perri (2005) for instance); this is the case in all the experiments that we report later on.

Regarding commercial banks, the effective collateral-loan ratio, $\kappa$, is set at 0.2 , to reflect inefficiencies in debt enforcement procedures in developing countries (see Djankov et al. (2008)). The elasticity of the repayment probability is set at $\varphi_{1}=0.1$ with respect to the effective collateral-loan ratio and $\varphi_{2}=0.3$ with respect to deviations in output from its steady state. Parameter $\theta_{0}^{F, B}$, which determines how bank foreign borrowing responds to the differential in the cost of domestic and foreign borrowing, is set at 0.16 ; this value implies that bank foreign liabilities represent initially about 10 percent of their total liabilities, a reasonable benchmark in view of the evidence. For the elasticities of substitution $\zeta^{D}$ and $\zeta^{L}$, which measure the degree of monopoly power in banking, there are no readily available model-based estimates for middle- 
income countries; accordingly, we set them to the values used by Dib (2010), 2.0 and 4.5 respectively.

Regarding the central bank, the reserve requirement rate $\mu^{R}$ is set at 0.1 , consistent with the data reported by Montoro and Moreno (2011) for some countries in Latin America. The degree of persistence in the central bank's policy response, $\chi$, is set at 0.8 whereas, consistent with estimates of Taylor-type rules for middle-income countries, responses of the base policy rate to inflation and output deviations, $\varepsilon_{1}$ and $\varepsilon_{2}$, are set at 2.0 and 0.5, respectively (see for instance Moura and Carvalho (2010)). The sensitivity of the penalty rate to the bank borrowing-required reserve ratio, $\theta_{0}^{C, B}$, to a low value initially, 0.1, which is sufficient to illustrate the main points of our analysis. The parameter characterizing the degree of exchange rate smoothing in the foreign reserves targeting rule, $\varphi_{1}^{R}$, is set at 0.5 initially, to reflect a relatively low degree of intervention. The relative weight in the trade motive for self insurance is assumed to be predominant (compared to the capital account motive) and accordingly the parameter $\varphi^{R}$ is set at 0.8 , whereas the degree of persistence in the rule, $\varphi_{2}^{R}$, is set also at 0.8. Given our focus on temporary capital controls, we set the initial value of $\tau^{B}$ equal to 0. As in Gertler et al. (2007) and Agénor et al. (2014), the share of government spending in output, $\psi$, is set at 0.2. Finally, the degree of persistence of the shock to the world risk-free rate, $\rho_{W}$, is set at 0.8 , which implies a fairly high degree of inertia.

\section{Drop in World Risk-Free Interest Rate}

To illustrate the impact of external financial shocks in the absence of capital controls, we consider a temporary drop in the world risk-free interest rate by 35 basis points at a quarterly rate, or about 141 basis points at an annual rate. The results of this experiment are displayed in Figure $1 .^{7}$

On impact, the shock lowers the return on foreign assets and the cost of borrowing abroad for domestic banks. Thus, households' holdings of foreign bonds decline, whereas bank foreign liabilities increase initially; both combine to generate an inflow of capital, which leads to an appreciation of the nominal exchange rate. Given that $\tau_{t}^{B}$

\footnotetext{
${ }^{7}$ The description of the transmission mechanism of a world interest rate shock differs here in several ways from Agénor et al. (2015); a key reason for that is that in the present case inflation increases on impact, despite the appreciation of the exchange rate, as a result of the increase in cyclical output and real wages.
} 
is constant in this experiment, the fall in the expected depreciation rate further lowers the (premium exclusive) cost of foreign borrowing measured in domestic currency terms, that is, the term $\left(1+\tau_{t}^{B}\right)\left(1+i_{t}^{W}\right) \mathbb{E}_{t}\left(E_{t+1} / E_{t}\right)$ in (38). As a result, the increase in bank foreign borrowing is magnified.

At the same time, the nominal appreciation lowers the domestic price of imported intermediate goods, which stimulates demand for this category of inputs and the production of final goods. It also tends to lower inflation (measured in terms of the price of domestic sales) but the increase in cyclical output, combined with higher real wages, tend to raise prices. The base policy rate therefore increases and so do the deposit and bond rates. However, because expected inflation increases by more, the real bond rate falls, thereby inducing households to increase consumption (as well as leisure) today. Moreover, the bond rate increases by more than the deposit rate, implying a reduction in bank deposits, as shown in the figure. Thus, despite the inflow of foreign borrowing, which tends to reduce bank borrowing from the monetary authority, the central bank borrowing-required reserves ratio increases, and so does the penalty rate. This, in turn, magnifies the increase in the refinance rate induced by a higher base policy rate. The higher cost of borrowing from the central bank tends to raise the loan rate. At the same time, however, the boom in economic activity, combined with a strong collateral effect (related to the increase in real house prices), tend to increase the probability of repayment. This effect dominates the increase in the refinance rate, implying therefore a fall in the loan rate.

In addition to an intertemporal effect on consumption, the fall in the real bond rate leads to an increase in the demand for housing services, which tends to raise real estate prices. In turn, this raises the value of the collateral that firms can pledge. But because the real loan rate falls initially, borrowing for investment outlays increases - so much so that the collateral-loan ratio falls, which tends to reduce the repayment probability. But because of the expansion of output, the net effect on the probability of repayment is positive. The nominal loan rate therefore falls. Thus, aggregate demand (spending on goods sold domestically) unambiguously increases on impact. In addition to the level effect on final output, there is also a composition effect: the appreciation of the nominal and real exchange rates translates into a drop in the share of final output allocated to exports, and an increase in the share sold domestically. Overall, the results of this experiment show that, consistent with the evidence, external shocks that lead to large 
inflows of capital generate a domestic boom characterized by increases in asset prices and aggregate demand, an expansion in output, inflationary pressures, real exchange rate appreciation, and a current account deficit.

\section{Optimal Simple Capital Controls Rule}

In the foregoing discussion it was assumed that the tax rate on bank capital flows, $\tau_{t}^{B}$, is kept constant. We consider now the case where the central bank implements countercyclical changes in the tax rate $\tau_{t}^{B}$ by relating it to changes in foreign bank borrowing:

$$
\frac{1+\tau_{t}^{B}}{1+\tilde{\tau}^{B}}=\left(\frac{1+\tau_{t-1}^{B}}{1+\tilde{\tau}^{B}}\right)^{\chi_{1}^{B}}\left\{\left(\frac{L_{t}^{F, B}}{L_{t-1}^{F, B}}\right)^{\chi_{2}^{B}}\right\}^{1-\chi_{1}^{B}},
$$

where $\chi_{1}^{B} \in(0,1)$ and $\chi_{2}^{B}>0$. To the extent that it raises the effective cost of foreign borrowing, this tax can be viewed as an unremunerated reserve requirement on banks' (net) foreign exchange liabilities, of the type used by Chile during the period 1991-98 (see Gallego et al. (2002)) and more recently by Brazil and Thailand (see Abhakorn and Tantisantiwong (2012) and Chamon and Garcia (2016)). It is also consistent with the "macroprudential levy" implemented in August 2011 by the Bank of Korea, in an attempt to dampen the growth in banks' foreign-currency liabilities, albeit without the maturity dimension (see Bruno and Shin (2014)). In practice, capital controls tend to take a permanent form or to be imposed during crisis (or pre-crisis) periods, rather than a time-varying rule of the type described in (54). ${ }^{8}$ Nevertheless, it provides a natural benchmark for a normative analysis of the benefits associated with market-based restrictions on cross-border bank-related capital flows, using simple, implementable rules. ${ }^{9}$

The results of the same interest rate experiment as described earlier are reported in Figure 2, together with the benchmark case, for $\chi_{1}^{B}=0.2$ (implying therefore low persistence) and $\chi_{2}^{B}=0.03$. They indicate that although interest rates and net private

\footnotetext{
${ }^{8}$ Fernández et al. (2013) examined the behavior of capital controls in 91 countries over the period 1995-2011. They found that these controls were acyclical, in the sense that policymakers did not seem to tighten capital controls on inflows or soften capital controls on outflows to curb expansions in aggregate activity, or overvaluations of the real exchange rate, or large current account deficits.

${ }^{9}$ Note also that in the model, in principle this form of capital controls could be seen as either microprudential or macroprudential - in the former case because it aims to mitigate financial risks at the level of the institution, and in the latter because its goal is to mitigate the volatility of (bankrelated) capital flows, and thus systemic financial risks (see Ostry et al. (2012)). However, given our focus on social welfare, we will consider (54) as fundamentally macroprudential in nature.
} 
capital inflows (defined as steady-state $\log$ deviations in $L_{t}^{F, B}-B_{t}^{F, P}$ ) appear to be more volatile, movements in cross-border bank borrowing, exchange rates, and the real economy appear to be dampened. Intuitively, the increase in the tax rate $\tau_{t}^{B}$ induced by the initial acceleration in bank foreign borrowing helps to mitigate the fall in the (premium exclusive) cost of foreign borrowing measured in domestic-currency terms, that is, the term $\left(1+\tau_{t}^{B}\right)\left(1+i_{t}^{W}\right) \mathbb{E}_{t}\left(E_{t+1} / E_{t}\right)$ in (38). As a result, the increase in bank foreign borrowing is partially reversed. In turn, this mitigates the impact of capital inflows on the nominal exchange rate, the domestic-currency price of imported intermediate goods, and therefore the expansionary effect of the shock on domestic output. At the same time, however, less foreign borrowing means (all else equal) more borrowing from the central bank, which in turn raises the cost at which commercial banks borrows domestically. On impact this increase is not large; it is however more persistent during a number of periods. Because investment depends on future movements in the loan rate, it tends to fall immediately. Concomitantly, a weaker appreciation mitigates on impact the downward effect of the pass-through on inflation, which also contributes to a higher policy rate. A more volatile refinance rate translates into larger fluctuations in market interest rates, and thus increased volatility in private holdings of foreign bonds. Movements in these flows tend to dominate those in cross-border bank borrowing, thereby explaining why fluctuations in total private capital flows are magnified. ${ }^{10}$ In fact, these conflicting effects on volatility are the fundamental reason why, as discussed later, a welfare-maximizing solution for $\tau_{t}^{B}$ (or, more precisely, an optimal value of the reaction parameter $\chi_{2}^{B}$ ) exists.

To assess the robustness of the previous results, two sensitivity tests are conducted; one with respect to $\chi_{1}^{B}$, and another with respect to a different determinant of capital controls. The first test involves a value of $\chi_{1}^{B}$ equal to 0.8 , to capture a high degree of inertia, while keeping $\chi_{2}^{B}$ at 0.03 . The results are shown in Figure 3. They show indeed that, with greater inertia, countercyclical capital controls mitigate volatility across the board - including, this time, in the bond rate and foreign exchange reserves. Intuitively, with a higher degree of inertia, capital controls respond relatively less to contemporaneous changes in bank foreign borrowing; all else equal, to maximize social welfare a more aggressive response is therefore needed.

\footnotetext{
${ }^{10} \mathrm{It}$ is also worth keeping in mind that we are focusing here only on capital controls on foreign bank borrowing; adding endogenous controls on household holdings of foreign bonds would naturally help to mitigate volatility of total private capital flows.
} 
The second test involves capital controls responding to a broad measure of activity, cyclical output. The rule is thus similar to (54), with $L_{t}^{F, B} / L_{t-1}^{F, B}$ replaced now by $Y_{t} / \tilde{Y}$. The results are reported in Figure 4, with a value of $\chi_{1}^{B}=1$ for illustrative purposes. They indicate that the rule performs even better than a rule that responds to bank foreign borrowing; all variables display less volatility now, including total private capital inflows. The key reason is that market interest rates are now less volatile, implying also less volatility in household holdings of foreign bonds. At the same time, however, it is important to note that a rule based on cyclical output may be more difficult to implement in real time, due to uncertainty associated with initial output estimates and subsequent (and sometimes large) revisions.

We then solve for the welfare-maximizing value of the reaction parameter $\chi_{2}^{B}$, based on a second-order approximation of the model and of expected lifetime utility (1), conditional on the initial steady state $(t=0)$ being the deterministic steady state (see Kim and Kim (2003) and Schmitt-Grohé and Uribe (2004)). As shown in Appendix $\mathrm{B}$, our measure of welfare, expressed in units of consumption, is

$$
\mathcal{W}_{t} \simeq \frac{\tilde{C}^{\varsigma^{-1}}}{1-\beta}\left\{\tilde{V}-\frac{1}{2 \varsigma} \tilde{C}^{1-\varsigma^{-1}} \operatorname{var}\left(\hat{C}_{t}\right)-\frac{\eta_{N} \tilde{N}^{2}}{2(\tilde{N}-1)^{2}} \operatorname{var}\left(\hat{N}_{t}\right)\right\}
$$

where $\operatorname{var}\left(\hat{C}_{t}\right)$ and $\operatorname{var}\left(\hat{N}_{t}\right)$ denote the unconditional variances of (the log deviations of) consumption and employment, and $\tilde{V}=\tilde{C}^{1-\varsigma^{-1}} /\left(1-\varsigma^{-1}\right)+\eta_{N} \ln (1-\tilde{N})$. Thus, because at time $t=0$ deviations of the model's variables from their steady-state values are zero, the second-order approximate solution relates social welfare solely to secondorder moments, namely, the volatility of private consumption and employment. ${ }^{11}$ Given the general equilibrium nature of the model, these measures also capture indirectly the effect of financial volatility. ${ }^{12}$

The results are displayed by the continuous line in Figure 5 for the rule based on bank foreign borrowing, a constant reserve requirement rate, and for $\chi_{1}^{B}=0.2$, again,

\footnotetext{
${ }^{11}$ Given that the housing market is always equilibrium, and that the supply of housing is constant, the volatility of real house prices does not enter our measure of welfare.

${ }^{12}$ In calculating welfare, we have followed the common practice of ignoring real money balances (see, for instance, Bergin et al. (2007) and De Fiore and Tristani (2013)). One way of justifying this choice is to note that there is a functional equivalence between using money as an argument of the utility function, and either entering it into liquidity costs (see Feenstra (1986)) or in a shopping time technology (see Croushore (1993)). Given this equivalence, accounting for money in the utility function is mainly a matter of convenience, rather than a reflection of a firm belief that it provides the proper micro-foundations of monetary theory. Ignoring it is therefore a sensible approach when evaluating welfare.
} 
to emphasize the fact that the proposed rule focuses on temporary controls. We use a grid step of 0.02 , which is sufficient for our purpose. The figure shows clearly that one can indeed define a welfare-maximizing capital controls rule; the optimal value of $\chi_{2}^{B}$ is 0.12 . This value can also be read directly from the first line of Table 2 . In addition, the table shows that a higher degree of persistence in the rule $\left(\chi_{1}^{B}=0.8\right)$ implies a higher optimal degree of aggressiveness in the rule, that is, $\chi_{2}^{B}=0.2$. Compared to the benchmark case of no policy intervention, the welfare gain is of the order of 0.5 percentage points with low persistence and 0.9 percentage points with high persistence.

Intuitively, the reason why a welfare-maximizing solution exists is because a more aggressive capital controls rule reduces volatility in the economy, but only up to a certain point. As noted earlier, such a policy reduces incentives for banks to borrow abroad, thereby mitigating the impact of the world interest rate shock on capital inflows, the nominal exchange rate, the domestic-currency price of imported intermediate goods, and thus on domestic output. At the same time, however, it increases the volatility of market interest rates. Initially, the former effect dominates and volatility of consumption and employment tends to fall, which implies that welfare increases. Beyond a certain point, however, the second effect begins to dominate; the increase in the volatility of market interest rates - namely, the loan rate, which affects private investment, and the bond rate, which affects the intertemporal allocation of consumption and the demand for bank deposits - is such that the net effect of a more aggressive capital controls policy is to increase the volatility of consumption and employment. The welfare-maximizing solution is the point at which the marginal benefits of a more aggressive policy are offset by the marginal costs. Put differently, it is never optimal to increase the tax on foreign borrowing to the point where it exactly offsets the drop in the world risk-free interest rate, thereby leaving the cost of foreign borrowing (given the expected depreciation rate) unchanged.

In this setting, the interest rate volatility channel operates mainly because of the assumption of imperfect substitutability between deposits and central bank borrowing. With perfect substitutability (so that $\theta_{0}^{C, B}=0$ in (46)), changes in bank foreign borrowing would have no direct effect on the central bank borrowing-required reserves ratio, and thus no direct impact on the refinance rate and market interest rates. Conversely, the higher $\theta_{0}^{C, B}$ is, the stronger would be the interest rate volatility channel associated with a more aggressive capital controls rule and the smaller should be the 
optimal value of $\chi_{2}^{B}$. This is indeed what is illustrated by the dotted line in Figure 5, which corresponds to $\theta_{0}^{C, B}=0.12$ instead of $\theta_{0}^{C, B}=0.1$ as in the benchmark case. The optimal value of the reaction parameter is now $\chi_{2}^{B}=0.08$, instead of 0.12 .

It is worth noting also that a qualitatively similar result can be obtained under perfect substitutability between deposits and central bank borrowing if we assume that banking activity involves a nonseparable cost between producing loans and funding sources. In such conditions, it can be easily be established that the loan rate would depend directly on the depreciation adjusted, premium-exclusive cost of foreign borrowing, $\left(1+\tau_{t}^{B}\right)\left(1+i_{t}^{F, B}\right) \mathbb{E}_{t}\left(E_{t+1} / E_{t}\right)$. However, we will continue to use specification (46) because imperfect substitutability between deposits and central bank borrowing is necessary in general to generate a countercyclical role for reserve requirements and because, as discussed next, we now turn to the welfare-maximizing combination of capital controls and reserve requirements.

To assess the performance of our optimal simple capital controls rule, we solve a Ramsey problem under which the central planner maximizes the social welfare subject to the private sector's optimizing conditions. The Ramsey planner chooses statecontingent allocations and prices to maximize welfare taking all the equilibrium conditions (except the capital controls rule) as given. To conduct welfare under the Ramsey optimal policy, we take a second-order approximation of all model equations, including the first-order conditions of the welfare maximization problem of the Ramsey planner. Following Woodford (2003), we focus on optimal commitment policy from a timeless perspective. ${ }^{13}$ Maximized welfare (relative to the benchmark case) is shown in the last line of Table 4. The results show that the optimal simple rule performs fairly well relative to the Ramsey policy; the gain associated with the latter is less than half of a basis point. In addition, as in Cúrdia and Woodford (2010) for instance, we assessed the closeness of the approximation by comparing the impulse responses under the optimal simple rule to those obtained under the Ramsey policy. The results (which are not reported here to save space) show again that the simple rule performs very well for all the main variables, compared to the Ramsey policy.

\footnotetext{
${ }^{13}$ Note that our model features distortions due to monopolistic competition on the goods market and financial frictions in the banking sector. We assume that subsidies are not available, so the decentralized equilibrium is not efficient - even in the nonstochastic equilibrium. Instead, as in most of the literature, we evaluate welfare around a distorted steady state and the constrained Ramsey planner can only achieve the second-best allocation.
} 


\section{Capital Controls and Reserve Requirements}

In the foregoing discussion it was assumed that the reserve requirement rate, $\mu_{t}^{R}$, is kept constant. As discussed at length in Agénor et al. (2015), in recent years policymakers in middle-income countries have often used reserve requirements as part of a countercyclical toolkit to mitigate macroeconomic fluctuations caused by the capital inflows. Accordingly, we consider now the case where the central bank implements both the countercyclical capital controls simple rule specified in (54) and an equallly simple, implementable countercyclical reserve requirement rule that relates (as in Agénor et al. (2015)) changes in $\mu_{t}^{R}$ to deviations in the ratio of bank loans to total output:

$$
\frac{1+\mu_{t}^{R}}{1+\tilde{\mu}^{R}}=\left(\frac{1+\mu_{t-1}^{R}}{1+\tilde{\mu}^{R}}\right)^{\chi_{1}^{R}}\left\{\left(\frac{l_{t}^{I} / Y_{t}}{\tilde{l}^{I} / \tilde{Y}}\right)^{\chi_{2}^{R}}\right\}^{1-\chi_{1}^{R}},
$$

where $\chi_{1}^{R} \in(0,1)$ and $\chi_{2}^{R}>0$.

The results are shown in Tables 2 and 3, for a capital controls rule involving either the change in bank foreign borrowing or cyclical output. There are two results that emerge from these tables. First, there is indeed an optimal combination of the reaction parameters in the countercyclical capital controls and reserve requirements rules that maximizes welfare. This combination is given by $\left(\chi_{2}^{B}=0.04, \chi_{2}^{R}=4\right)$ for a low degree of persistence in the capital controls rule $\left(\chi_{1}^{B}=0.2\right)$ and by $\left(\chi_{2}^{B}=0.12, \chi_{2}^{R}=16\right)$ for a high degree of persistence in the capital controls rule $\left(\chi_{1}^{B}=0.8\right)$, when the rule is specified in terms of changes in foreign bank borrowing (see in Table 2). Similar results are obtained when the rule is specified in terms of cyclical output, as shown in Table 3, where the grid step is now 2. This provides some rationale for the evidence suggesting that a number of middle-income countries have in recent years used both instruments to respond to swings in capital flows. The results also suggest that these instruments are complements, in the sense that in general both are needed to maximize welfare. Compared to the benchmark case of no policy intervention, the welfare gain associated with the welfare-maximizing policy is now of the order of 0.8 percentage points regardless of the degree of persistence in the capital controls rule.

Intuitively, the two policies are complements because, even though they operate through different channels, they both help to mitigate real and financial volatility. Capital controls operate through their direct impact on bank foreign borrowing and ultimately, as noted earlier, through their dampening effect on the initial downward 
movement in the loan rate. Reserve requirements, by contrast, operate through household portfolio allocation. A higher reserve requirement rate lowers the deposit rate and thus bank deposits. In the model, the drop in deposits is large enough to dominate the initial increase in foreign borrowing induced by lower world interest rates; as a result, commercial bank borrowing from the central bank increases, thereby raising the penalty rate, the refinance rate, and mitigating the initial drop in the loan rate. ${ }^{14}$ Thus, the two policies reinforce each other to the extent that they both contribute to maintainig market borrowing costs for capital producers at a higher level than they would otherwise be.

Second, and more importantly, the tables also show that when the response of both instruments is determined jointly, a more aggressive reserve requirement rule reduces reliance on capital controls - regardless of what they respond to. For instance, with a high degree of persistence in the capital controls rule $\left(\chi_{1}^{B}=0.8\right)$, the optimal response of capital controls to a change in bank foreign borrowing is 0.12 instead of 0.2 , whereas the degree of aggressiveness in the reserve requirements rule increases from 0 to 16 (see Table 2). In that sense, countercyclical reserve requirements and capital controls can be viewed as partial substitutes (at the margin) in maximizing welfare. Intuitively, the capital controls rule generates faster decreasing marginal returns (in terms of welfare) than the reserve requirements rule; thus, combining the two instruments makes the relationship between the degree of policy aggressiveness and welfare less concave, thereby generating a superior outcome with less reliance on restrictions on bank foreign borrowing. For the same reason the reverse does not hold; adding capital controls as a secondary instrument to countercyclical reserve requirements implies a more aggressive use of both instruments. Thus, there is asymmetric substitution between the two policy instruments.

Finally, although the focus of this paper has been on welfare, it is worth considering the behavior of individual volatility measures under alternative policy regimes. Table 4 compares the asymptotic standard deviations of key variables under five cases, following the same world risk-free interest rate shock discussed earlier: no countercyclical

\footnotetext{
${ }^{14}$ As can be inferred from (46), even when central bank borrowing rises, the penalty rate could fall if the level of required reserves increases significantly. This could occur because, as can be inferred from (31), movements in $\mu_{t}^{R}$ and $d_{t}$ operate in opposite directions. Given our calibration, the net effect on required reserves is positive but relatively small, implying indeed that the penalty rate increases. See Agénor et al. (2015) for a more detailed discussion of countercyclical reserve requirement rules in an open economy.
} 
policies $\left(\chi_{2}^{B}=\chi_{2}^{R}=0\right)$, optimal capital controls $\left(\chi_{2}^{B}=0.12\right)$, the Ramsey optimal policy, optimal reserve requirements $\left(\chi_{2}^{R}=2\right)$, and optimal combination of the two simple rules $\left(\chi_{2}^{B}=0.04, \chi_{2}^{R}=4\right)$. The table confirms that capital controls and reserve requirements are highly effective in terms of mitigating the volatility of key macroeconomic and financial variables, and that the optimal capital controls rule performs well compared to the Ramsey optimal policy. ${ }^{15}$ The results also suggest that these tools are in general complements, meaning that their combination leads to the lowest levels of volatility for all the key real and financial variables. Indeed, if macroeconomic stability is defined in terms of the volatility of output and inflation, and financial stability (as in several recent contributions) in terms of the volatility of the credit-to-output ratio and the volatility of real house prices - two variables that have often been associated with financial crises - the results show that capital controls, especially when they are combined with countercyclical reserve requirements, are highly effective at promoting economic stability. Put differently, our welfare-based results are consistent with those that one would obtain by using an arbitrary policy loss function specified in terms of commonly-used measures of macroeconomic and financial stability.

\section{Concluding Remarks}

Dramatic shifts in capital flows into and out of many middle-income countries over the past few years have led some researcher and policymakers to question whether an open capital market is always welfare maximizing. Specifically, it has been shown that surges in capital flows can lead to excessive asset price volatility in these countries. If the terms at which agents borrow in these economies depend on collateral values, these fluctuations in asset prices act to magnify fluctuations in economic activity. In such conditions, there may be a role for policy to control these excessive capital inflows and outflows and reduce volatility in collateral values.

This paper studied the performance of time-varying capital controls on cross-border bank borrowing in an open-economy model with credit market imperfections and imperfect capital mobility. The model was parameterized for a middle-income country and was shown to replicate the main stylized facts associated with a shock to the

\footnotetext{
${ }^{15}$ Note that, in line with the foregoing discussion, the welfare-maximizing policies always imply a more volatile nominal bond rate. However, consumption, which depends on the real bond rate, is always less volatile.
} 
world risk-free interest rate (capital inflows, real appreciation, credit boom, asset price pressures, and an expansion in economic activity). A simple, implementable capital controls rule, based on changes in bank borrowing abroad, was then specified. Because its goal is to mitigate the volatility of (bank-related) capital flows, and thus indirectly financial volatility, the rule is fundamentally macroprudential in nature. A welfare-maximizing policy, defined in terms of the degree of aggressiveness of the rule, was established numerically. In addition, it was shown that the optimal simple capital controls rule performs well relative to the Ramsey policy.

The analysis was next extended to solve jointly for optimal countercyclical reserve requirements and capital controls simple rules, implying that the two instruments are in general complements. Put differently, if reserve requirements are viewed as an implicit tax on financial intermediation, it is optimal to tax banks on both components of their market funding sources at a business cycle frequency. However, and more importantly, it was also shown that a more aggressive reserve requirement rule (which responds to the credit-output ratio) induces less reliance on capital controls; thus, the two instruments are partial substitutes from the perspective of welfare maximization. These results remain qualitatively unchanged when the countercyclical capital controls rule displays persistence or responds to cyclical output. Beyond the specific tools considered here, our results have broader implications for the ongoing debate regarding the extent to which countercyclical macroprudential instruments are complements or substitutes in promoting financial stability.

A useful extension would be to study the role of distortions associated with leakages in implementing capital controls. By and large, the evidence suggests that incentives to evade restrictions on capital flows become stronger over time when they take a permanent form. The capital controls rule studied in this paper operates at a business cycle frequency; it is therefore less likely to induce this type of distortions. Nevertheless, it is possible that even in the short term tighter restrictions on bank foreign borrowing (as discussed here) may lead to a shift in the behavior of the nonfinancial private sector which is such that it weakens the performance of these controls. A related issue is the possibility, as documented by Beirne and Friedrich (2014) and Bruno et al. (2017), that controls on some types of inflows may lead over time to substitution or spillover effects. A key question then is whether there are important gains from capital controls despite the existence of leakages - as discussed by Bengui and Bianchi (2014) 
in a different setting - or cross-flow effects, and more generally given the ability of the financial system to circumvent regulatory and prudential standards.

Another useful extension would be to study the impact of capital controls in a multi-country world. There has been a growing number of contributions that account for the spillover effects of capital controls. Forbes et al. (2016) for instance found portfolio effects (indirect effects) and externalities from capital controls in Brazil, and they suggested that the assessment of capital controls should consider their effects on portfolio effects to other countries. Similarly, Fratzscher (2014), Ghosh et al. (2014), and Giordani et al. (2017) found evidence of cross-border spillovers whereby capital controls imposed by countries are associated with larger flows to other countries. They also argued that capital account restrictions can significantly influence the volume of cross-border flows. Finally, focusing on a sample of Latin-American countries, Lambert et al. (2011) investigated the potential spillover effects that capital account restrictions imposed on one country may have on neighboring countries. They also found that a rise in the Brazilian tax on capital inflows had negative cross-border externalities. A multi-country analysis of capital controls that internalizes this type of spillover effects could help to define optimal rules for the global economy. 


\section{References}

Abhakorn, Pongrapeeporn, and Nongnuch Tantisantiwong, "A Reexamination of Capital Controls' Effectiveness: Recent Experience of Thailand," Journal of Asian Economics, 23 (February 2012), 26-38.

Agénor, Pierre-Richard, "International Financial Integration: Benefits, Costs, and Policy Challenges," in Survey of International Finance, ed. by H. Kent Baker and Leigh A. Riddick, eds., Oxford University Press (Oxford: 2012).

Agénor, Pierre-Richard, Koray Alper, and Luiz Pereira da Silva, "Sudden Floods, Macroprudential Regulation, and Stability in an Open Economy," Journal of International Money and Finance, 48 (November 2014), 68-100.

—_, "External Shocks, Financial Volatility and Reserve Requirements in an Open Economy," Working Paper No. 203, Centre for Growth and Business Cycle Research (March 2015). Forthcoming, Journal of International Money and Finance.

Agénor, Pierre-Richard, and Peter J. Montiel, Development Macroeconomics, 4rd ed., Princeton University Press (Princeton, New Jersey: 2015).

Agénor, Pierre-Richard, and Luiz Pereira da Silva, Inflation Targeting and Financial Stability, Inter-American Development Bank (Washington DC: 2013).

—_ "Cyclically Adjusted Provisions and Financial Stability," Journal of Financial Stability, 28 (February 2017), 143-62.

Allen, Franklin, Elena Carletti, and Robert Marquez, "Credit Market Competition and Capital Regulation," Review of Financial Studies, 24 (April 2011), 983-1018.

Barnea, Emanuel, Yoram Landskroner, and Meir Sokoler, "Monetary Policy and Financial Stability in a Banking Economy: Transmission Mechanism and Policy Tradeoffs," Journal of Financial Stability, 18 (June 2015), 78-90.

Beirne, John, and Christian Friedrich, "Capital Flows and Macroprudential Policies: A Multilateral Assessment of Effectiveness and Externalities," Working Paper No. 1721, European Central Bank (August 2014).

Bengui, Julien, and Javier Bianchi, "Capital Flow Management when Capital Controls Leak," unpublished, University of Wisconsin (June 2014).

Benigno, Gianluca, Huigang Chen, Christopher Otrok, Alessandro Rebucci, and Eric R. Young, "Optimal Capital Controls and Real Exchange Rate Policies: A Pecuniary Externality Perspective," Journal of Monetary Economics, 84 (December 2016), 14765.

Bergin, Paul R., Hyung-Cheol Shin, and Ivan Tchakarov, "Does Exchange Rate Variability Matter for Welfare? A Quantitative Investigation of Stabilization Policies," European Economic Review, 51 (May 2007), 1041-58.

Bianchi, Javier, "Overborrowing and Systemic Externalities in the Business Cycle," American Economic Review, 101 (December 2011), 3400-26.

Bianchi, Javier, and Enrique G. Mendoza, "Overborrowing, Financial Crises and 'Macroprudential' Policy," Working Paper No. 11/24, International Monetary Fund (February 2011).

Binici, Mahir, Michael Hutchison, and Martin Schindler, "Controlling Capital? Legal Restrictions and the Asset Composition of International Financial Flows," Journal of International Money and Finance, 29 (June 2010), 666-84. 
Brunnermeier, Markus K., and Yuliy Sannikov, "International Credit Flows and Pecuniary Externalities," American Economic Journal: Macroeconomics, 7 (January 2015), 297338.

Bruno, Valentina, Ilhyock Shim, and Hyun Song Shin, "Comparative Assessment of Macroprudential Policies," Journal of Financial Stability, 28 (February 2017), 183-202.

Bruno, Valentina, and Hyun Song Shin, "Assessing Macroprudential Policies: Case of South Korea," Scandinavian Journal of Economics, 116 (January 2014), 128-57.

_ - "Capital Flows and the Risk-Taking Channel of Monetary Policy," Journal of Monetary Economics, 71 (April 2015), 119-32.

Caballero, Julián A., "Do Surges in International Capital Inflows Influence the Likelihood of Banking Crises?," Economic Journal, 126 (March 2016), 281-316.

Carvalho, Fabia A. de, Marcos R. Castro, and Silvio M. A. Costa, "Traditional and Matterof-Fact Financial Frictions in a DSGE Model for Brazil: The Role of Macroprudential Instruments and Monetary policy," Working Paper No 460, Bank for International Settlements (September 2014).

Cerutti, Eugenio, "Drivers of Cross-Border Banking Exposures during the Crisis," Journal of Banking and Finance, 55 (June 2015), 340-57.

Chamon, Marcos, and Marcio Garcia, "Capital Controls in Brazil: Effective?," Journal of International Money and Finance, 61 (March 2016), 163-87.

Chang, Chun, Zheng Liu, and Mark M. Spiegel, "Capital Controls and Optimal Chinese Monetary Policy," Journal of Monetary Economics, 74 (September 2015), 1-15.

Claessens, Stijn, "Global Banking: Recent Developments and Insights from Research," Review of Finance, 21 (July 2017), 1513-55.

Coenen, Günter, Giovanni Lombardo, Frank Smets, and Roland Straub, "International Transmission and Monetary Policy Cooperation," in International Dimensions of Monetary Policy, ed. by Jordi Galí and Mark Gertler, University of Chicago Press (Chicago, Ill.: 2009).

Committee on International Economic Policy and Reform, "Banks and Cross-Border Capital Flows: Policy Challenges and Regulatory Responses," Brookings Institution (Washington DC: 2012).

Cordero, José A., and Juan A. Montecino, Capital Controls and Monetary Policy in Developing Countries, Center for Economic and Policy Research (Washington DC: 2010).

Costinot, Arnaud, Guido Lorenzoni, and Iván Werning, "A Theory of Capital Controls as Dynamic Terms-of-Trade Manipulation," Journal of Political Economy, 122 (February 2014), 77-128.

Croushore, Dean, "Money in the Utility Function: Functional Equivalence to a ShoppingTime Model," Journal of Macroeconomics, 15 (December 1993), 175-82.

Cúrdia, Vasco, and Michael Woodford, "Credit Spreads and Monetary Policy," Journal of Money, Credit and Banking, 42 (September 2010), 3-35.

Daude, Christian, Eduardo Levy Yeyati, and Arne J. Nagengast, "On the Effectiveness of Exchange Rate Interventions in Emerging Markets," Journal of International Money and Finance, (June 2016), 239-61.

Davis, Scott, and Ignacio Presno, "Capital Controls as an Instrument of Monetary Policy," Journal of Monetary Economics, forthcoming (June 2017).

De Fiore, Fiorella, and Oreste Tristani, "Optimal Monetary Policy in a Model of the Credit Channel," Economic Journal, 123 (September 2013), 906-31. 
Dell'Ariccia, Giovanni, Luc Laeven, and Robert Marquez, "Real Interest Rates, Leverage, and Bank Risk-Taking," Journal of Economic Theory, 149 (January 2014), 65-99.

De Paoli, Bianca, and Anna Lipinska, "Capital Controls: A Normative Analysis," Staff Report No. 600, Federal Reserve Bank of New York (February 2013).

Devereux, Michael B., and James Yetman, "Capital Controls, Global Liquidity Traps, and the International Policy Dilemma," Scandinavian Journal of Economics, 116 (March 2014), 158-89.

Dib, Ali, "Banks, Credit Market Frictions, and Business Cycles," Working Paper No. 2010-24, Bank of Canada (October 2010).

Djankov, Simeon, Oliver Hart, Caralee McLiesh, and Andrei Shleifer, "Debt Enforcement around the World," Journal of Political Economy, 116 (December 2008), 1105-49.

Dooley, Michael, "A Survey of Literature on Controls over International Capital Transactions," IMF Staff Papers, 43 (December 1996), 639-87.

Edwards, Sebastian, "The Federal Reserve, the Emerging Markets, and Capital Controls: A High-Frequency Empirical Investigation," Journal of Money, Credit and Banking, 44 (December 2012), 151-84.

Eichengreen, Barry, and Andrew Rose, "Capital Controls in the 21st Century," Policy Insight No. 72, Centre for Economic Policy Research (June 2014).

Escudé, Guillermo J., "The Possible Trinity: Optimal Interest Rate, Exchange Rate, and Taxes on Capital Flows in a DSGE Model for a Small Open Economy," Working Paper No. 2014-13, Kiel Institute for the World Economy (March 2014).

Farhi, Emmanuel, and Iván Werning, "Dealing with the Trilemma: Optimal Capital Controls with Fixed Exchange Rates," Working Paper No. 18280, National Bureau of Economic Research (June 2012).

Feenstra, Robert C., "Functional Equivalence between Liquidity Costs and the Utility of Money," Journal of Monetary Economics, 17 (March 1986), 271-91.

Fernández, Andrés, Alessandro Rebucci, and Martín Uribe, "Are Capital Controls Countercyclical?," Journal of Monetary Economics, 76 (November 2015), 1-14.

Forbes, Kristin, Marcel Fratzscher, Thomas Kostka, and Roland Straub, "Bubble thy Neighbour: Portfolio Effects and Externalities from Capital Controls," Journal of International Economics, 99 (March 2016), 85-104.

Forbes, Kristin, Marcel Fratzscher, and Roland Straub, "Capital-Flow Management Measures: What are they Good for?," Journal of International Economics, 96 (July 2015), s76-s97.

Fratzscher, Marcel, "Capital Flow Policies, Monetary Policy and Coordination," in Financial Flows and Infrastructure Financing, ed. by Alexandra Heath and Matthew Read, Reserve Bank of Australia (Sidney: 2014).

Gallego, Francisco, Leonardo Hernández, and Klaus Schmidt-Hebbel, "Capital Controls in Chile: Were they Effective?," in Banking, Financial Integration, and International Crises, ed. by Leonardo Hernández and Klaus Schmidt-Hebbel, Central Bank of Chile (Santiago: 2002).

Gertler, Mark, Simon Gilchrist, and Fabio M. Natalucci, "External Constraints on Monetary Policy and the Financial Accelerator," Journal of Money, Credit and Banking, 39 (March 2007), 295-330.

Ghosh, Atish R., Mahvash S. Qureshi, and Naotaka Sugawara, "Regulating Capital Flows at both Ends: Does it Work?," Working Paper No. 4/188, International Monetary 
Fund (October 2014).

Ghosh, Atish R., Jonathan D. Ostry, and Mahvash S. Qureshi, "Managing the Tide: How Do Emerging Markets Respond to Capital Flows?," Working Paper No. 17/69, International Monetary Fund (March 2017).

Giordani, Paolo E., Michele Ruta, Hans Weisfeld, and Ling Zhu, "Capital Flow Deflection," Journal of International Economics, forthcoming (June 2017).

Heathcote, Jonathan, and Fabrizio Perri, "On the Desirability of Capital Controls," IMF Economic Review, 64 (March 2016), 75-102.

Herrmann, Sabine, and Dubravko Mihaljek, "The Determinants of Cross-Border Bank Flows to Emerging Markets: New Empirical Evidence on the Spread of Financial Crises," Economics of Transition, 21 (July 2013) 1-27.

Hoggarth, Glenn, Lavan Mahadeva, and Jeremy Martin, "Understanding International Bank Capital Flows during the recent Financial Crisis," Financial Stability Paper No. 8, Bank of England (September 2010).

Inter-American Development Bank, The Labyrinth: How Can Latin America and the Caribbean Navigate the Global Economy, Latin American and Caribbean Macroeconomic Report, IDB Publications (Washington DC: 2015).

International Monetary Fund, Global Financial Stability Report: Meeting New Challenges to Stability and Building a Safer System, IMF Publications (Washington DC: 2010).

—- The Liberalization and Management of Capital Flows: An Institutional View, IMF Publications (Washington DC: 2012).

Kim, Jinill, and Sunghyun Henry Kim, "Spurious Welfare Reversals in International Business Cycle Models," Journal of International Economics, 60 (August 2003), 471-500.

Kitano, Shigeto, and Kenya Takaku, "A Comparison between Optimal Capital Controls under Fixed Exchange Rates and Optimal Monetary Policy under Flexible Rates," Discussion Paper No. 2014-25, Kobe University (May 2014).

Klein, Michael, "Capital Controls: Gates vs. Walls," Working Paper No. 18526, National Bureau of Economic Research (November 2012).

Korinek, Anton, and Damiano Sandri, "Capital Controls or Macroprudential Regulation?," Working Paper No. 20805, National Bureau of Economic Research (December 2014).

Lambert, Frederic, Julio Ramos-Tallada and Cyril Rebilard, "Capital Controls and Spillover Effects: Evidence from Latin American Countries," Working Paper No. 357, Banque de France (December 2011).

Li, Jie, and Ramkishen S. Rajan, "Do Capital Controls make Gross Equity Flows to Emerging Markets less Volatile?," Journal of International Money and Finance, 59 (December 2015), 220-44.

Magud, Nicolas E., Carmen M. Reinhart, and Kenneth S. Rogoff, "Capital Controls: Myth and Reality-A Portfolio Balance Approach," Working Paper No. 16805, National Bureau of Economic Research ((February 2011).

McCauley, Robert N., Agustín S. Bénétrix, Patrick M. McGuire and Peter von Goetz, "Financial Deglobalisation in Banking?," Working Paper No. 650, Bank for International Settlements (June 2017).

Medina, Juan Pablo, and Jorge Roldós, "Monetary and Macroprudential Policies to Manage Capital Flows," Working Paper No. 14/30, International Monetary Fund (February 2014). 
Molnar, Margit, Yusuke Tateno, and Amornrut Supornsinchai, "Capital Flows in AsiaPacific: Controls, Bonanzas and Sudden Stops," Working Paper No. 320, OECD Development Centre (September 2013).

Montoro, Carlos, and Ramon Moreno, "The Use of Reserve Requirements as a Policy Instrument in Latin America," BIS Quarterly Review (March 2011), 53-65.

Moura, Marcelo L., and Alexandre de Carvalho, "What can Taylor Rules Say about Monetary Policy in Latin America?," Journal of Macroeconomics, 32 (March 2010), 392-404.

Neumeyer, Pablo A., and Fabrizio Perri, "Business Cycles in Emerging Economies: The Role of Interest Rates," Journal of Monetary Economics, 52 (March 2005), 345-80.

Ostry, Jonathan, Atish Ghosh, Marcos Chamon, and Mahvash Qureshi, "Tools for Managing Financial-Stability Risks from Capital Inflows," Journal of International Economics, 88 (November 2012), 407-21.

Reinhardt, Dennis, and Steven J. Riddiough, "The Two Faces of Cross-Border Banking Flows: An Investigation into the Links between Global Risk, Arms-Length Funding and Internal Capital Markets," Working Paper No. 498, Bank of England (April 2014).

Schmitt-Grohé, Stephanie, and Martín Uribe, "Solving Dynamic General Equilibrium Models using a Second-Order Approximation to the Policy Function," Journal of Economic Dynamics and Control, 28 (January 2004), 755-75.

—_, "Prudential Policy for Peggers," Working Paper No. 18031, National Bureau of Economic Research (May 2012).

Woodford, Michael, Interest and Prices: Foundations of a Theory of Monetary Policy, Princeton University Press (Princeton, N.J.: 2003).

You, Yu, Yoonbai Kim, and Xiaomei Ren, "Do Capital Controls Enhance Monetary Independence?," Review of Development Economics, 18 (August 2014), 475-89. 
Table 1

Benchmark Parameterization: Key Parameter Values

\begin{tabular}{|c|c|c|}
\hline Parameter & Value & Description \\
\hline \multicolumn{3}{|l|}{ Household } \\
\hline$\beta$ & 0.985 & Discount factor \\
\hline$\varsigma$ & 0.5 & Elasticity of intertemporal substitution \\
\hline$\eta_{N}$ & 10.0 & Preference parameter for leisure \\
\hline$\eta_{x}$ & 0.02 & Preference parameter for money holdings \\
\hline$\eta_{H}$ & 0.02 & Preference parameter for housing \\
\hline$\nu$ & 0.35 & Share parameter in index of money holdings \\
\hline$\theta_{0}^{F, P}$ & 0.5 & Sensitivity of risk premium, household foreign bonds \\
\hline \multicolumn{3}{|l|}{ Production } \\
\hline$\Lambda_{D}$ & 0.7 & distribution parameter, final good \\
\hline$\eta$ & 1.5 & Elasticity of substitution, baskets of IG goods \\
\hline$\mu^{F}$ & 0.3 & Exchange rate pass-through, imported intermediate goods \\
\hline$\varkappa$ & 0.9 & Price elasticity of exports \\
\hline$\theta_{D}, \theta_{F}$ & 10.0 & Elasticity of demand, intermediate goods \\
\hline$\alpha$ & 0.35 & Share of capital, domestic intermediate goods \\
\hline$\phi_{D}$ & 74.5 & Adjustment cost parameter, domestic IG prices \\
\hline$\delta$ & 0.02 & Depreciation rate of capital \\
\hline$\Theta_{K}$ & 14 & Adjustment cost parameter, investment \\
\hline \multicolumn{3}{|c|}{ Commercial banks } \\
\hline$\kappa$ & 0.2 & Effective collateral-loan ratio \\
\hline$\varphi_{1}$ & 0.1 & Elasticity of repayment probability, collateral \\
\hline$\varphi_{2}$ & 0.3 & Elasticity of repayment probability, cyclical output \\
\hline$\zeta^{D}$ & 2.0 & Elasticity of substitution, deposits \\
\hline$\zeta^{L}$ & 4.5 & Elasticity of substitution, loans to CG producers \\
\hline$\theta_{0}^{F, B}$ & 0.16 & Sensitivity of risk premium, bank foreign borrowing \\
\hline \multicolumn{3}{|l|}{ Central bank } \\
\hline$\mu^{R}$ & 0.1 & Reserve requirement rate \\
\hline$\chi$ & 0.8 & Degree of interest rate smoothing \\
\hline$\varphi^{R}$ & 0.2 & Speed of adjustment to reserve target \\
\hline$\varepsilon_{1}$ & 2.0 & Response of base policy rate to inflation deviations \\
\hline$\varepsilon_{2}$ & 0.5 & Response of base policy rate to output deviations \\
\hline$\theta_{0}^{C, B}$ & 0.1 & Sensitivity of penalty rate to borrowing-reserves ratio \\
\hline$\varphi_{1}^{R}$ & 0.5 & Exchange rate smoothing parameter, foreign reserves rule \\
\hline$\varphi_{2}^{R}$ & 0.8 & Persistence parameter, foreign reserves rule \\
\hline$\varphi^{R}$ & 0.8 & Relative weight on trade motive, foreign reserves rule \\
\hline$\chi_{1}^{B}$ & 0.2 & Persistence parameter, capital controls rule \\
\hline$\chi_{1}^{R}$ & 0.1 & Persistence parameter, reserve requirements rule \\
\hline \multicolumn{3}{|l|}{ Government } \\
\hline$\psi$ & 0.2 & Share of government spending in domestic output sales \\
\hline \multicolumn{3}{|r|}{$\cos _{0}$} \\
\hline$\rho_{W}$ & 0.8 & Persistence parameter, shock to world risk-free rate \\
\hline
\end{tabular}


Table 2

Optimal Degree of Aggressiveness of the Capital Controls Rule and Reserve Requirements Rule (Capital Controls Rule Responding to Change in Bank Foreign Borrowing)

\begin{tabular}{|c|c|c|c|c|c|c|c|c|c|c|c|}
\hline \multirow[b]{2}{*}{$\chi_{2}^{R}$} & \multicolumn{11}{|c|}{$\chi_{2}^{B}$} \\
\hline & 0 & 0.04 & 0.08 & 0.12 & 0.16 & 0.20 & 0.24 & 0.28 & 0.32 & 0.36 & 0.40 \\
\hline \multicolumn{12}{|c|}{ Low degree of persistence in capital controls rule, $\chi_{1}^{\mathrm{B}}=0.2$} \\
\hline 0 & 1.0000 & 1.0007 & 1.0010 & 1.0011 & 1.0010 & 1.0009 & 1.0009 & 1.0008 & 1.0007 & 1.0007 & 1.0006 \\
\hline 2 & 1.0032 & 1.0043 & 1.0037 & 1.0026 & 1.0015 & 1.0005 & 0.9997 & 0.9990 & 0.9984 & 0.9979 & 0.9975 \\
\hline 4 & 1.0020 & 1.0045 & 1.0043 & 1.0032 & 1.0018 & 1.0006 & 0.9995 & 0.9985 & 0.9977 & 0.9970 & 0.9963 \\
\hline 6 & 1.0003 & 1.0041 & 1.0044 & 1.0034 & 1.0021 & 1.0008 & 0.9995 & 0.9985 & 0.9975 & 0.9967 & 0.9960 \\
\hline 8 & 0.9989 & 1.0035 & 1.0044 & 1.0036 & 1.0023 & 1.0010 & 0.9997 & 0.9986 & 0.9976 & 0.9967 & 0.9959 \\
\hline 10 & 0.9976 & 1.0030 & 1.0043 & 1.0037 & 1.0025 & 1.0012 & 0.9999 & 0.9988 & 0.9977 & 0.9968 & 0.9960 \\
\hline 12 & 0.9965 & 1.0025 & 1.0041 & 1.0037 & 1.0026 & 1.0013 & 1.0001 & 0.9989 & 0.9979 & 0.9969 & 0.9961 \\
\hline 14 & 0.9956 & 1.0021 & 1.0040 & 1.0037 & 1.0027 & 1.0015 & 1.0003 & 0.9991 & 0.9981 & 0.9971 & 0.9963 \\
\hline 16 & 0.9949 & 1.0018 & 1.0039 & 1.0037 & 1.0028 & 1.0016 & 1.0004 & 0.9993 & 0.9983 & 0.9973 & 0.9964 \\
\hline 18 & 0.9942 & 1.0015 & 1.0038 & 1.0037 & 1.0029 & 1.0017 & 1.0006 & 0.9995 & 0.9984 & 0.9975 & 0.9966 \\
\hline 20 & 0.9936 & 1.0012 & 1.0037 & 1.0037 & 1.0029 & 1.0018 & 1.0007 & 0.9996 & 0.9986 & 0.9976 & 0.9968 \\
\hline
\end{tabular}

High degree of persistence in capital controls rule, $\chi^{\mathrm{B}}{ }_{1}=0.8$

\begin{tabular}{llllllllllll}
0 & 1.0000 & 1.0020 & 1.0030 & 1.0035 & 1.0037 & 1.0038 & 1.0037 & 1.0037 & 1.0036 & 1.0036 & 1.0035 \\
2 & 1.0039 & 1.0066 & 1.0071 & 1.0068 & 1.0062 & 1.0055 & 1.0048 & 1.0041 & 1.0035 & 1.0029 & 1.0024 \\
4 & 1.0028 & 1.0071 & 1.0082 & 1.0080 & 1.0073 & 1.0064 & 1.0055 & 1.0046 & 1.0038 & 1.0030 & 1.0023 \\
6 & 1.0011 & 1.0068 & 1.0085 & 1.0086 & 1.0079 & 1.0070 & 1.0060 & 1.0050 & 1.0040 & 1.0032 & 1.0023 \\
8 & 0.9996 & 1.0064 & 1.0086 & 1.0088 & 1.0082 & 1.0074 & 1.0063 & 1.0053 & 1.0043 & 1.0034 & 1.0025 \\
10 & 0.9983 & 1.0059 & 1.0085 & 1.0089 & 1.0085 & 1.0076 & 1.0066 & 1.0056 & 1.0046 & 1.0036 & 1.0027 \\
12 & 0.9972 & 1.0055 & 1.0084 & 1.0090 & 1.0086 & 1.0078 & 1.0068 & 1.0058 & 1.0048 & 1.0038 & 1.0029 \\
14 & 0.9963 & 1.0051 & 1.0083 & 1.0090 & 1.0087 & 1.0080 & 1.0070 & 1.0060 & 1.0050 & 1.0040 & 1.0031 \\
16 & 0.9956 & 1.0048 & 1.0082 & 1.0090 & 1.0088 & 1.0081 & 1.0072 & 1.0062 & 1.0052 & 1.0042 & 1.0033 \\
18 & 0.9949 & 1.0045 & 1.0081 & 1.0090 & 1.0089 & 1.0082 & 1.0073 & 1.0063 & 1.0053 & 1.0044 & 1.0034 \\
20 & 0.9943 & 1.0042 & 1.0079 & 1.0090 & 1.0089 & 1.0083 & 1.0074 & 1.0065 & 1.0055 & 1.0045 & 1.0036 \\
\hline \hline
\end{tabular}

Note: Entries in this table represent welfare, measured in terms of consumption units, relative to the benchmark case where there are no rules under operation, that is, the case of $\chi_{2}^{B}=\chi_{2}^{R}=0$.

Source: Authors' calculations. 
Table 3

Optimal Degree of Aggressiveness of the Capital Controls Rule and Reserve Requirements Rule (Capital Controls Rule Responding to Cyclical Output'

\begin{tabular}{|c|c|c|c|c|c|c|c|c|c|c|c|}
\hline \multirow[b]{2}{*}{$\chi_{2}^{\mathrm{R}}$} & \multicolumn{11}{|c|}{$\overline{\chi_{2}^{B}}$} \\
\hline & 0 & 2 & 4 & 6 & 8 & 10 & 12 & 14 & 16 & 18 & 20 \\
\hline \multicolumn{12}{|c|}{ Low degree of persistence in capital controls rule, $\chi_{1}^{\mathrm{B}}=0.2$} \\
\hline 0 & 1.00000 & 1.00312 & 1.00356 & 1.00367 & 1.00371 & 1.00373 & 1.00374 & 1.00374 & 1.00374 & 1.00374 & 1.00374 \\
\hline 2 & 1.00324 & 1.00660 & 1.00652 & 1.00620 & 1.00592 & 1.00569 & 1.00552 & 1.00538 & 1.00526 & 1.00517 & 1.00509 \\
\hline 4 & 1.00200 & 1.00722 & 1.00777 & 1.00759 & 1.00730 & 1.00704 & 1.00681 & 1.00661 & 1.00645 & 1.00630 & 1.00618 \\
\hline 6 & 1.00035 & 1.00672 & 1.00806 & 1.00823 & 1.00810 & 1.00791 & 1.00770 & 1.00751 & 1.00734 & 1.00719 & 1.00706 \\
\hline 8 & 0.99885 & 1.00577 & 1.00779 & 1.00836 & 1.00845 & 1.00839 & 1.00827 & 1.00812 & 1.00798 & 1.00785 & 1.00772 \\
\hline 10 & 0.99759 & 1.00466 & 1.00716 & 1.00809 & 1.00844 & 1.00854 & 1.00852 & 1.00846 & 1.00837 & 1.00828 & 1.00818 \\
\hline 12 & 0.99653 & 1.00351 & 1.00631 & 1.00753 & 1.00811 & 1.00837 & 1.00849 & 1.00852 & 1.00850 & 1.00846 & 1.00840 \\
\hline 14 & 0.99563 & 1.00237 & 1.00530 & 1.00672 & 1.00748 & 1.00791 & 1.00815 & 1.00828 & 1.00834 & 1.00837 & 1.00836 \\
\hline 16 & 0.99487 & 1.00127 & 1.00418 & 1.00570 & 1.00659 & 1.00714 & 1.00749 & 1.00771 & 1.00786 & 1.00794 & 1.00799 \\
\hline 18 & 0.99422 & 1.00023 & 1.00299 & 1.00449 & 1.00542 & 1.00604 & 1.00647 & 1.00677 & 1.00698 & 1.00712 & 1.00722 \\
\hline 20 & 0.99365 & 0.99923 & 1.00174 & 1.00310 & 1.00398 & 1.00459 & 1.00504 & 1.00537 & 1.00561 & 1.00579 & 1.00592 \\
\hline \multicolumn{12}{|c|}{ High degree of persistence in capital controls rule, $\chi_{1}^{\mathrm{B}}=0.8$} \\
\hline 0 & 1.00000 & 1.00309 & 1.00353 & 1.00365 & 1.00369 & 1.00371 & 1.00372 & 1.00373 & 1.00373 & 1.00373 & 1.00373 \\
\hline 2 & 1.00324 & 1.00658 & 1.00663 & 1.00638 & 1.00612 & 1.00591 & 1.00573 & 1.00559 & 1.00547 & 1.00536 & 1.00527 \\
\hline 4 & 1.00200 & 1.00702 & 1.00772 & 1.00767 & 1.00747 & 1.00725 & 1.00704 & 1.00686 & 1.00670 & 1.00656 & 1.00643 \\
\hline 6 & 1.00035 & 1.00640 & 1.00784 & 1.00816 & 1.00814 & 1.00802 & 1.00787 & 1.00771 & 1.00756 & 1.00743 & 1.00730 \\
\hline 8 & 0.99885 & 1.00540 & 1.00743 & 1.00812 & 1.00835 & 1.00838 & 1.00832 & 1.00823 & 1.00813 & 1.00802 & 1.00791 \\
\hline 10 & 0.99759 & 1.00427 & 1.00671 & 1.00774 & 1.00820 & 1.00839 & 1.00846 & 1.00846 & 1.00841 & 1.00836 & 1.00829 \\
\hline 12 & 0.99653 & 1.00312 & 1.00581 & 1.00709 & 1.00775 & 1.00811 & 1.00831 & 1.00840 & 1.00844 & 1.00844 & 1.00842 \\
\hline 14 & 0.99563 & 1.00201 & 1.00479 & 1.00623 & 1.00706 & 1.00756 & 1.00787 & 1.00806 & 1.00818 & 1.00825 & 1.00828 \\
\hline 16 & 0.99487 & 1.00095 & 1.00369 & 1.00519 & 1.00612 & 1.00672 & 1.00713 & 1.00741 & 1.00760 & 1.00773 & 1.00782 \\
\hline 18 & 0.99422 & 0.99995 & 1.00254 & 1.00400 & 1.00495 & 1.00560 & 1.00607 & 1.00641 & 1.00666 & 1.00684 & 1.00697 \\
\hline 20 & 0.99365 & 0.99900 & 1.00135 & 1.00267 & 1.00354 & 1.00417 & 1.00464 & 1.00499 & 1.00527 & 1.00547 & 1.00563 \\
\hline
\end{tabular}

Note: Entries in this table represent welfare, measured in terms of consumption units, relative to the benchmark case where there are no are no rules under operation, that is, the case of $\chi_{2}^{B}=\chi_{2}^{R}=0$.

Source: Authors' calculations. 
Table 4

Asymptotic Standard Deviations of Key Variables under Alternative Policy Regimes

\begin{tabular}{lccccc}
\hline \hline & $\begin{array}{c}\text { No counter- } \\
\text { cyclical policies }\end{array}$ & $\begin{array}{c}\text { Optimal } \\
\text { capital controls }\end{array}$ & $\begin{array}{c}\text { Ramsey } \\
\text { policy }\end{array}$ & $\begin{array}{c}\text { Optimal } \\
\text { res. requirements }\end{array}$ & $\begin{array}{c}\text { Optimal } \\
\text { combination }\end{array}$ \\
\hline \hline Real variables & & & & & \\
Domestic sales, final good & 0.0035 & 0.0022 & 0.0021 & 0.0018 & 0.0012 \\
Employment & 0.0020 & 0.0019 & 0.0017 & 0.0013 & 0.0012 \\
Investment & 0.0078 & 0.0049 & 0.0044 & 0.0038 & 0.0025 \\
Consumption & 0.0010 & 0.0008 & 0.0007 & 0.0007 & 0.0006 \\
Real exchange rate & 0.0034 & 0.0028 & 0.0025 & 0.0040 & 0.0026 \\
Exports & 0.0031 & 0.0025 & 0.0025 & 0.0036 & 0.0023 \\
Price inflation & 0.0010 & 0.0011 & 0.0010 & 0.0009 & 0.0001 \\
Financial variables & & & & & 0.0016 \\
Base policy rate & 0.0023 & 0.0024 & 0.0019 & 0.0018 & 0.0007 \\
Refinance rate & 0.0019 & 0.0020 & 0.0018 & 0.0017 & 0.0002 \\
Loan rate & 0.0011 & 0.0006 & 0.0005 & 0.0003 & 0.0013 \\
Loan-refinance rate spread & 0.0028 & 0.0024 & 0.0026 & 0.0016 & 0.0005 \\
Government bond rate & 0.0004 & 0.0006 & 0.0006 & 0.0006 & 0.0012 \\
Real house prices & 0.0020 & 0.0016 & 0.0018 & 0.0015 & 0.0004 \\
Repayment probability & 0.0010 & 0.0007 & 0.0006 & 0.0005 & 0.0014 \\
Loan-to-output ratio & 0.0043 & 0.0027 & 0.0021 & 0.0020 & 0.3539 \\
Bank foreign borrowing & 0.3818 & 0.3591 & 0.3176 & 0.3952 & 0.1763 \\
Private capital inflows & 0.1485 & 0.1933 & 0.1424 & 0.1364 & 0.0025 \\
Official foreign reserves & 0.0024 & 0.0035 & 0.0033 & 0.0026 & 1.0045 \\
Maximized welfare & -- & 1.0011 & 1.0016 & 1.0032 & \\
\hline \hline
\end{tabular}

Note: Entries in the last line represent welfare, measured in terms of consumption units, relative to the benchmark case (no countercyclical policies). The results in columns 2, 3 and 4 are calculated for $\chi_{1}^{B}=0.2$. 
Figure 1

Experiment: Transitory Drop in the World Risk-Free interest Rate

Benchmark Case

(Deviations from steady state)
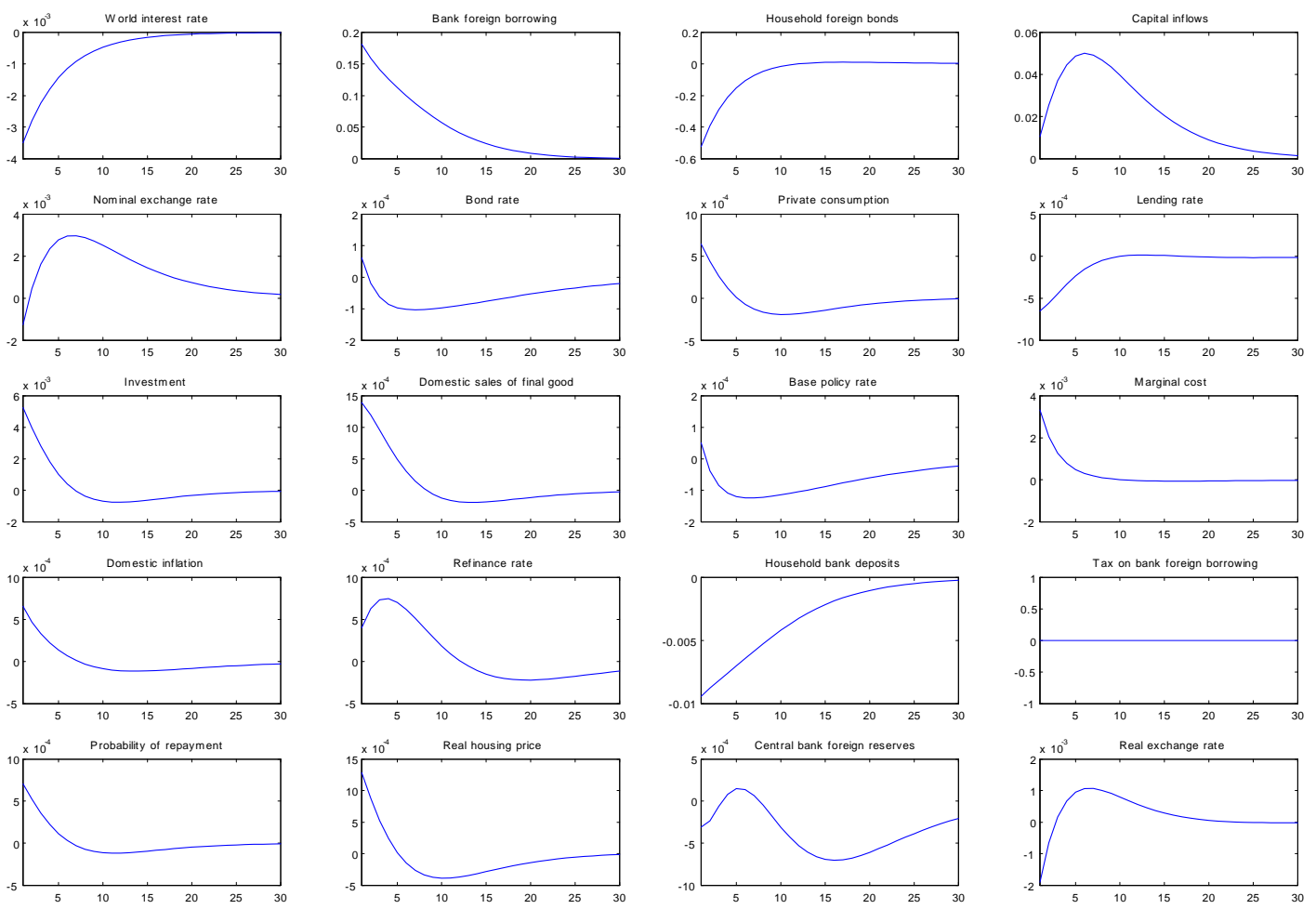

Note: Interest rates, inflation, and the repayment probability are measured in absolute deviations, that is, in the relevant graphs a value of 0.05 for these variables corresponds to a 5 percentage point deviation in absolute terms. The real exchange rate is defined as the ratio of the nominal exchange rate divided by the price of final goods. 


\section{Figure 2}

Experiment: Transitory Drop in the World Risk-Free interest Rate Benchmark Case and Endogenous Countercyclical Capital Controls Rule, $\chi_{1}^{B}=0.2, \chi_{2}^{B}=0.03$

(Deviations from steady state)
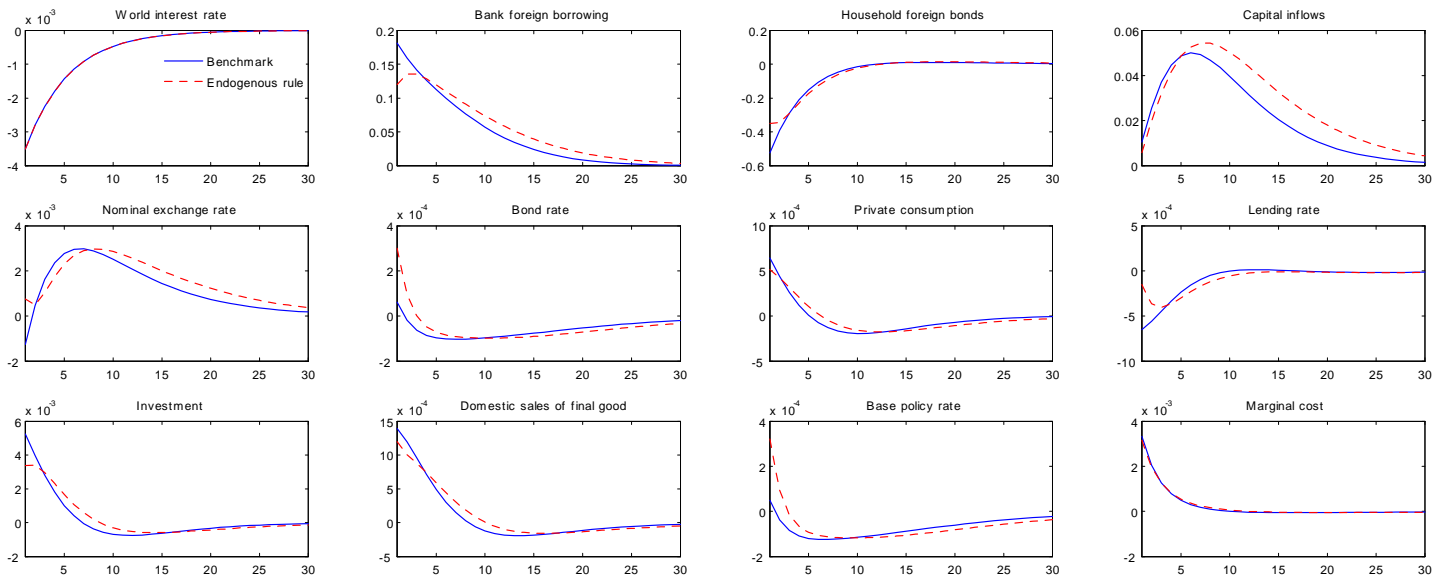

Marginal cost
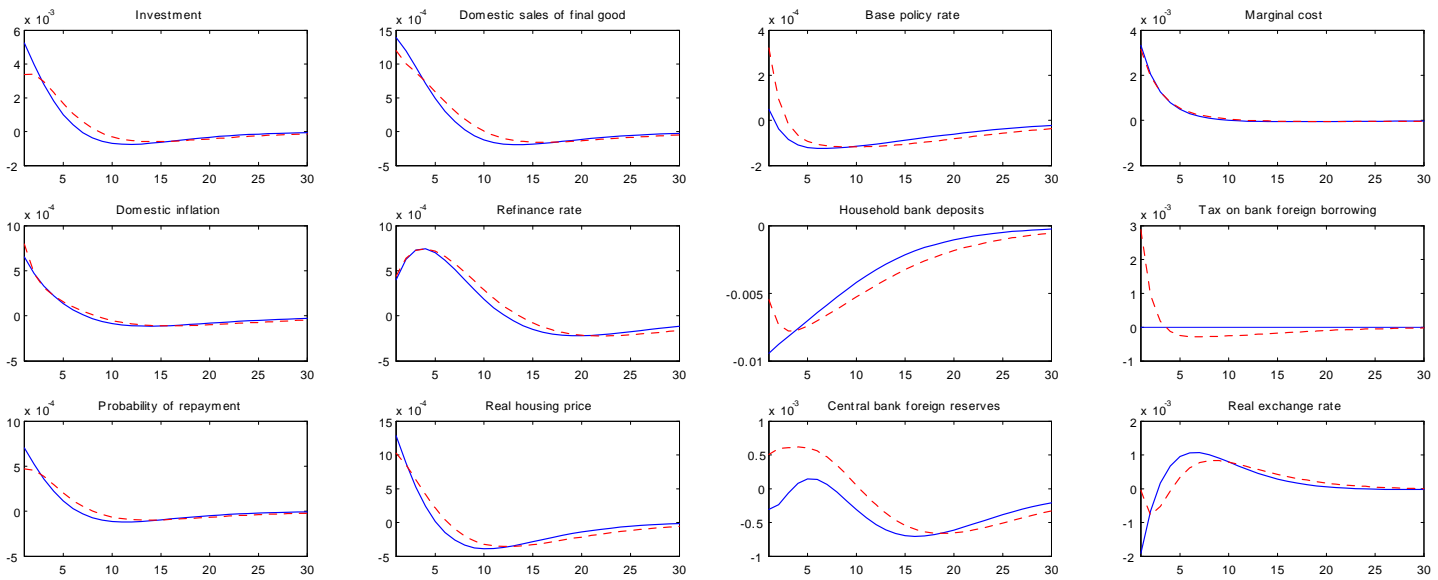

Note: Interest rates, inflation, and the repayment probability are measured in absolute deviations, that is, in the relevant graphs a value of 0.05 for these variables corresponds to a 5 percentage point deviation in absolute terms. The real exchange rate is defined as the ratio of the nominal exchange rate divided by the price of final goods. 


\section{Figure 3}

Experiment: Transitory Drop in the World Risk-Free interest Rate Alternative Endogenous Countercyclical Capital Controls Rule, $\chi_{1}^{B}=0.2$ and $\chi_{1}^{B}=0.8$

(Deviations from steady state)
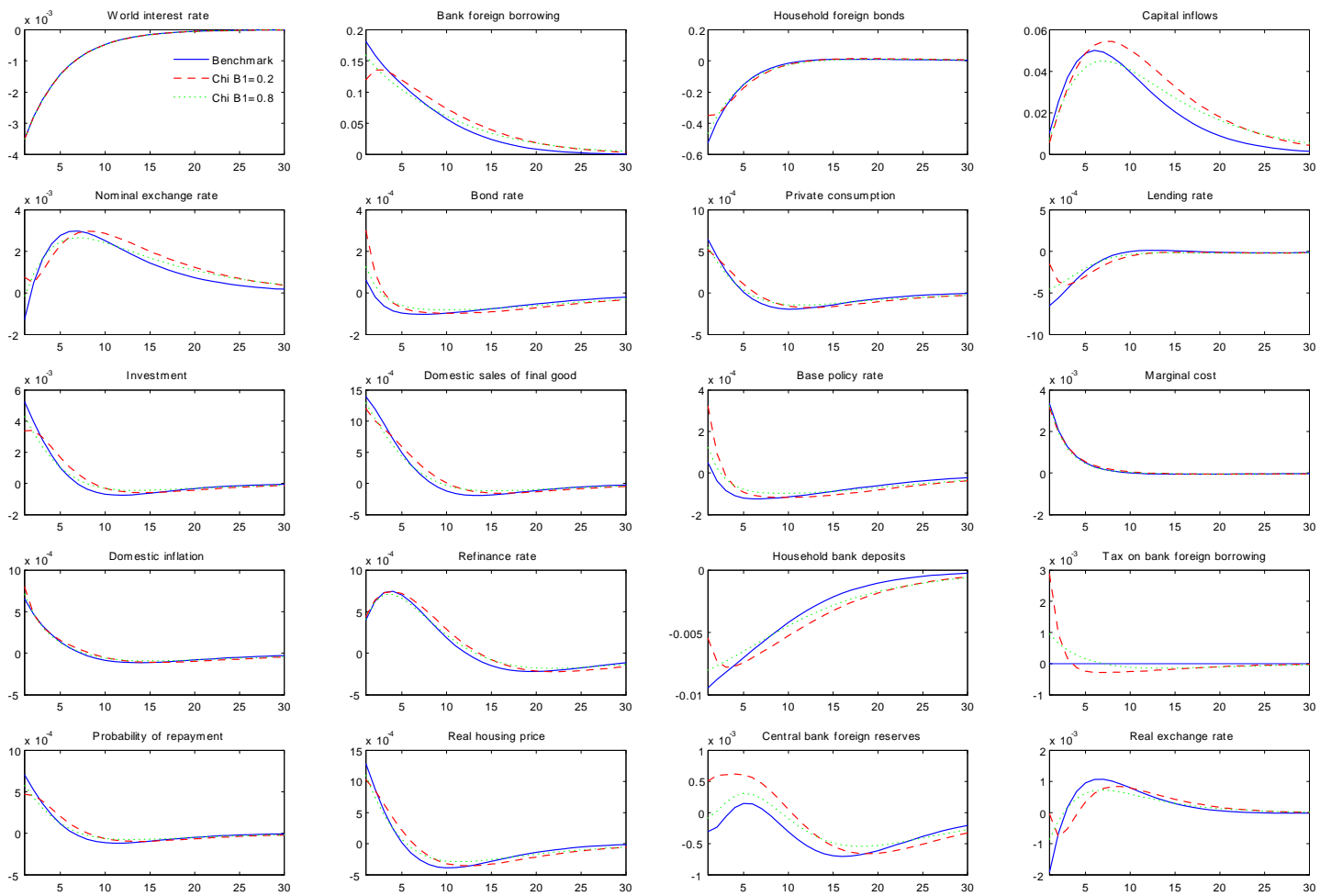

Note: Interest rates, inflation, and the repayment probability are measured in absolute deviations, that is, in the relevant graphs a value of 0.05 for these variables corresponds to a 5 percentage point deviation in absolute terms. The real exchange rate is defined as the ratio of the nominal exchange rate divided by the price of final goods. 


\section{Figure 4}

Experiment: Transitory Drop in the World Risk-Free interest Rate Benchmark Case and Endogenous Countercyclical Capital Controls Rule Responding to Cyclical Output, $\chi_{1}^{B}=0.2, \chi_{2}^{B}=1$

(Deviations from steady state)
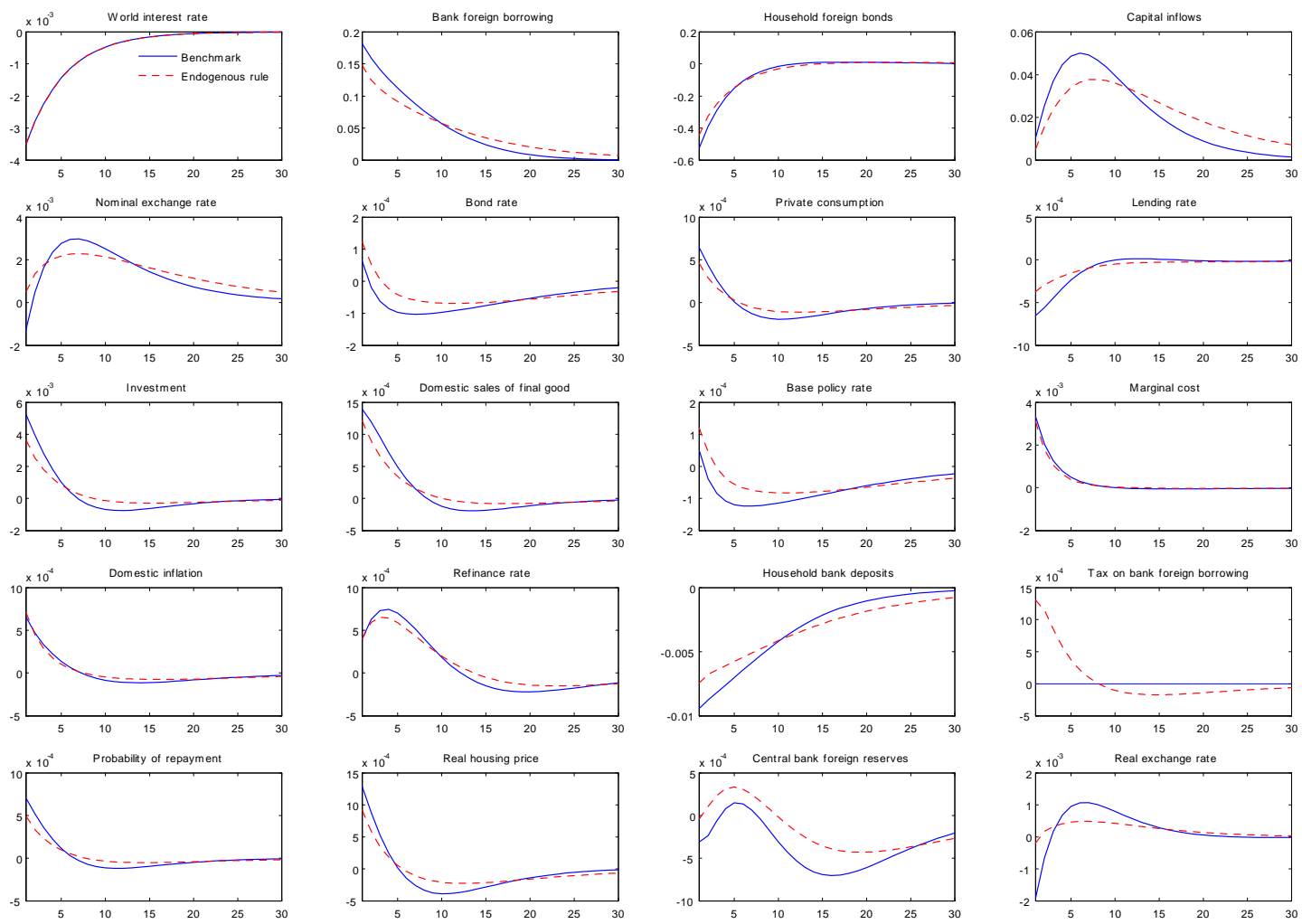

Note: Interest rates, inflation, and the repayment probability are measured in absolute deviations, that is, in the relevant graphs a value of 0.05 for these variables corresponds to a 5 percentage point deviation in absolute terms. The real exchange rate is defined as the ratio of the nominal exchange rate divided by the price of final goods. 


\section{Figure 5}

Social Welfare and the Degree of Aggressiveness of Capital Controls to Changes in Bank Foreign Borrowing

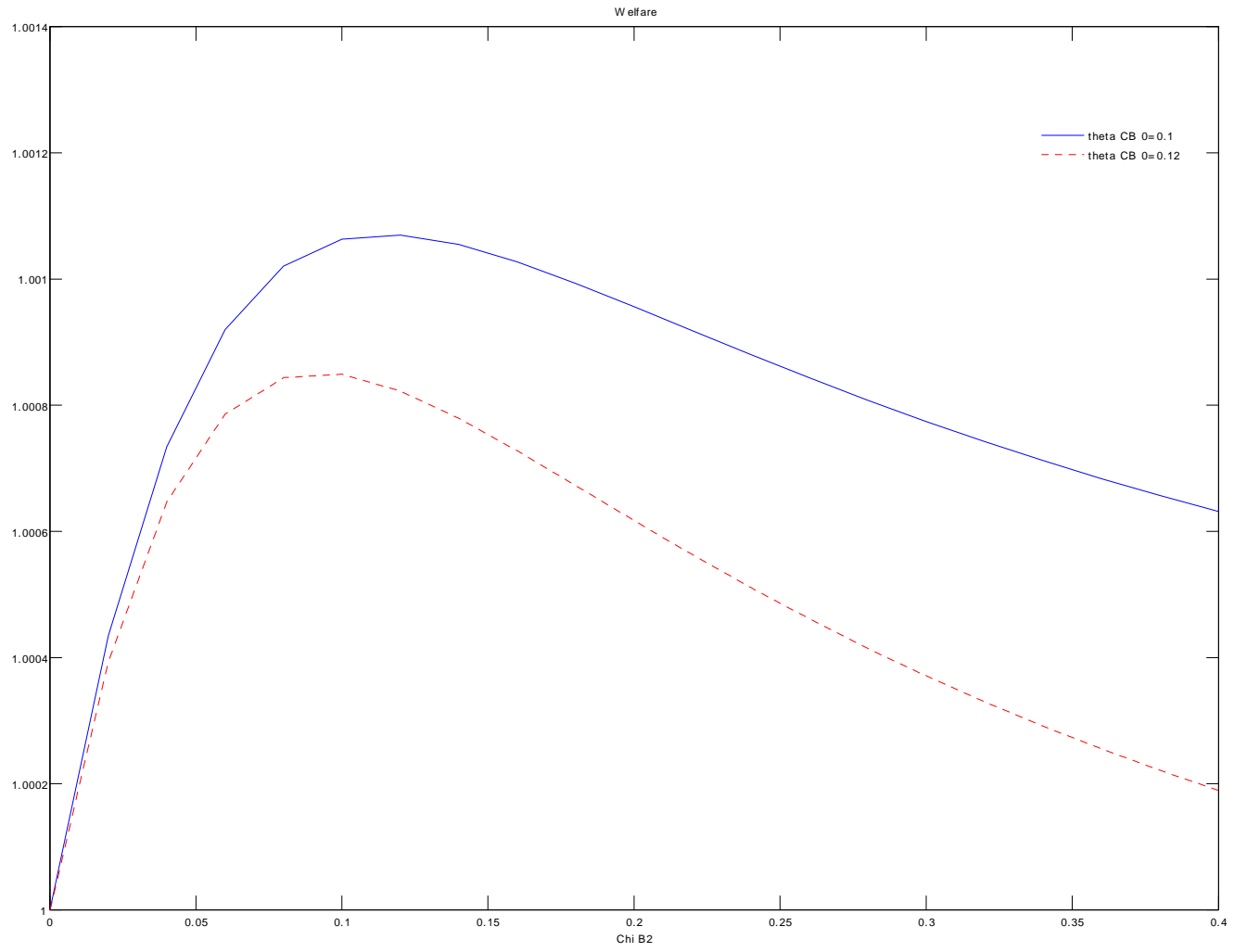

Note: The rule is based on bank foreign borrowing and $\chi_{1}^{B}=0.2$. The value of $\chi_{2}^{B}$ in the capital controls rule is calculated on the basis of a second-order approximation of the utility function and the equations of the model. Values on the vertical axis of this graph represent welfare, measured in terms of consumption units, relative to the benchmark case where there are no rules under operation, that is, the case of $\chi_{2}^{B}=\chi_{2}^{R}=0$. 